\title{
Heavy Metal-Resistant Filamentous Fungi as Potential Mercury Bioremediators
}

\author{
Cristina L. Văcar ${ }^{1,2}$, Enikö Covaci ${ }^{3,4} \oplus$, Somsubhra Chakraborty ${ }^{5}$, Bin Li $^{6}{ }^{6}$, David C. Weindorf ${ }^{7}$, \\ Tiberiu Frentiu ${ }^{3,4} \mathbb{1}$, Marcel Pârvu ${ }^{2,8}$ 这 and Dorina Podar ${ }^{1,2, * \mathbb{D}}$
}

check for

updates

Citation: Văcar, C.L.; Covaci, E.; Chakraborty, S.; Li, B.; Weindorf, D.C.; Frențiu, T.; Pârvu, M.; Podar, D. Heavy Metal-Resistant Filamentous Fungi as Potential Mercury Bioremediators. J. Fungi 2021, 7, 386. https://doi.org/10.3390/jof7050386

Academic Editors:

Thomas Edison E. dela Cruz and Fahrul Huyop

Received: 23 April 2021

Accepted: 11 May 2021

Published: 14 May 2021

Publisher's Note: MDPI stays neutral with regard to jurisdictional claims in published maps and institutional affiliations.

Copyright: (c) 2021 by the authors. Licensee MDPI, Basel, Switzerland. This article is an open access article distributed under the terms and conditions of the Creative Commons Attribution (CC BY) license (https:// creativecommons.org/licenses/by/ $4.0 /)$.
1 Department of Molecular Biology and Biotechnology, Babeș-Bolyai University, 1 Kogălniceanu St., 400084 Cluj-Napoca, Romania; cristina.vacar@ubbcluj.ro

2 Centre for Systems Biology, Biodiversity and Bioresources (3B), Babeș-Bolyai University, 3-5 Clinicilor St., 400015 Cluj-Napoca, Romania; marcel.parvu@ubbcluj.ro

3 Department of Analytical Chemistry, Babeș-Bolyai University, 11 Arany Janos St., 400028 Cluj-Napoca, Romania; eniko.covaci@ubbcluj.ro (E.C.); tiberiu.frentiu@ubbcluj.ro (T.F.)

4 Research Center for Advanced Analysis, Instrumentation and Chemometrics, Babeș-Bolyai University, 11 Arany Janos St., 400028 Cluj-Napoca, Romania

5 Agricultural and Food Engineering Department, Indian Institute of Technology, Kharagpur 721302, India; somzcall@gmail.com

6 Department of Experimental Statistics, Louisiana State University, Baton Rouge, LA 70803, USA; bli@lsu.edu

7 Department of Earth and Atmospheric Sciences, Central Michigan University, 1200 S. Franklin St.,

Mount Pleasant, MI 48859, USA; weind1dc@cmich.edu

8 Department of Taxonomy and Ecology, Babeș-Bolyai University, 44 Republicii St., 400015 Cluj-Napoca, Romania

* Correspondence: dorina.podar@ubbcluj.ro

Abstract: Filamentous fungi native to heavy metals (HMs) contaminated sites have great potential for bioremediation, yet are still often underexploited. This research aimed to assess the HMs resistance and $\mathrm{Hg}$ remediation capacity of fungi isolated from the rhizosphere of plants resident on highly $\mathrm{Hg}$-contaminated substrate. Analysis of $\mathrm{Hg}, \mathrm{Pb}, \mathrm{Cu}, \mathrm{Zn}$, and $\mathrm{Cd}$ concentrations by $\mathrm{X}$-ray spectrometry generated the ecological risk of the rhizosphere soil. A total of $32 \mathrm{HM}$-resistant fungal isolates were molecularly identified. Their resistance spectrum for the investigated elements was characterized by tolerance indices (TIs) and minimum inhibitory concentrations (MICs). Clustering analysis of TIs was coupled with isolates' phylogeny to evaluate HMs resistance patterns. The bioremediation potential of five isolates' live biomasses, in $100 \mathrm{mg} / \mathrm{L} \mathrm{Hg}^{2+}$ aqueous solution over $48 \mathrm{~h}$ at $120 \mathrm{r} / \mathrm{min}$, was quantified by atomic absorption spectrometry. New species or genera that were previously unrelated to $\mathrm{Hg}$-contaminated substrates were identified. Ascomycota representatives were common, diverse, and exhibited varied HMs resistance spectra, especially towards the elements with ecological risk, in contrast to Mucoromycota-recovered isolates. HMs resistance patterns were similar within phylogenetically related clades, although isolate specific resistance occurred. Cladosporium sp., Didymella glomerata, Fusarium oxysporum, Phoma costaricensis, and Sarocladium kiliense isolates displayed very high MIC (mg/L) for $\mathrm{Hg}$ (140-200), in addition to $\mathrm{Pb}$ (1568), $\mathrm{Cu}(381)$, Zn (2092-2353), or Cd (337). The Hg biosorption capacity of these highly Hg-resistant species ranged from 33.8 to $54.9 \mathrm{mg} / \mathrm{g}$ dry weight, with a removal capacity from $47 \%$ to $97 \%$. Thus, the fungi identified herein showed great potential as bioremediators for highly Hg-contaminated aqueous substrates.

Keywords: mercury; mycoremediation; heavy metal resistance; Fusarium sp.; Sarocladium sp.; biosorption; contaminated soil; bioremediation; biotechnology

\section{Introduction}

Heavy metals (HMs) are harmful for biological systems when present in excess and can often accumulate, as they are non-biodegradable [1]. HM contamination is an incon- 
spicuous and persistent issue threatening environmental safety and human health [2]. Anthropogenic activities substantially contribute to worldwide HM dispersal in soil, water, and the atmosphere [3]. Estimates indicate up to 2.5 million potentially contaminated sites in Europe alone [4-6]. Municipal and industrial waste treatment and disposal, and mining activities, are among the major sources of HMs contamination in European soils [5]. Over the past five decades, single metal pollution of surface water has shifted to mixed metal pollution, and an increasing number of metals are surpassing World Health Organization (WHO) and US Environmental Protection Agency (USEPA) standard threshold concentrations [7]. Mercury $(\mathrm{Hg})$ is of special concern for human health, as it is highly mobile in the environment and tends to bioaccumulate and further biomagnify through food webs [8-10]. Industrial and wastewater discharge, mining, coal combustion, and chloralkali industries were estimated to have increased the elemental $\left.\mathrm{Hg}_{(\mathrm{Hg}}{ }^{0}\right)$ release into the atmosphere, above natural levels, by 1- to 4.5-fold, eventually increasing redeposition rates [11-13]. Elevated concentrations of $\mathrm{Hg}^{0}$, constantly generated by chloralkali plants, endanger the stability of ecosystems and human health in areas extending several $\mathrm{km}$ away from the point source [14-19]. Moreover, $\mathrm{Hg}$ atmospheric residence time and currents promote its global distribution, spreading the contamination to unspoiled areas [10].

Transboundary Hg contamination threatens human and ecosystem health, which is why coordinated preventive actions are undertaken globally to monitor and reduce its spread, and to regulate $\mathrm{Hg}$ usage and waste disposal [20]. Areas around point sources of HM pollution require urgent interventions to reclaim environmental safety and reduce adverse effects on human health. However, conventional techniques such as vitrification, incineration, excavation of landfill, soil washing, solidification, or electro-kinetic system stabilization imply high costs, intensive labor, subsequent dispersal, and irreversible changes in soil quality, structure, and essential activities of native microbiota [21-23]. Therefore, identifying low cost and less invasive technologies is necessary for addressing the remediation of HM-contaminated sites. In situ bioremediation approaches, i.e., biostimulation, biosparging, bioventing, and bioaugmentation [24-26], or microorganisms-assisted phytoremediation [27-29], have been recently considered for the decontamination of HMs contaminated soils. The use of bioremediation technologies can prevent secondary HMs dispersal and unnecessary human exposure can be avoided.

Mycoremediation is a type of bioremediation that employs fungi for removal, degradation, or toxicity reduction of numerous contaminants from various substrates [30]. Filamentous fungi exhibit essential characteristics that recommend them as effective HM bioremediation agents. Fungal cells have high surface area with excellent HM-binding properties due to negative charges of functional groups present in cell wall components [31,32]. Additionally, fungi possess multiple antioxidant systems, metal transporters, metal-buffering molecules, metal-transformation enzymes, vacuolar sequestration abilities, and secrete metal-precipitating compounds; however, few mechanisms have been characterized in filamentous fungi [25,33-35]. Not only are they cosmopolitan microorganisms, but they are also frequently more resilient than bacteria in metalliferous soils [36-38] and have the ability to colonize porous matrices with their hyphae networks. Research on fungi in relation to $\mathrm{Hg}$ has indicated several potential mycoremediation candidates, all of which have been isolated from HM-contaminated backgrounds [39-41]. The need for HM resistant fungi autochthonous to a contaminated site has been recently emphasized for in situ mycoremediation approaches [31,42-44]. The advantages are obvious: these isolates are already adapted to site-specific conditions, especially to competition within local communities, and are equipped with resistance/tolerance mechanisms that may account for toxicity reduction or removal of HMs at the site [31,42-44]. Lab-scale and greenhouse experiments validate soil HM mycoremediation performance [24,31,39]. Similarly, effective recovery of HMs from contaminated water by fungi as biosorbents has also been demonstrated at small-scales [45-48]. Fungal biosorbents were extensively studied by previous researchers [46-52]. However, the complexity of the biosorption process, development, and cost effectiveness of adequate techniques for large-scale application await further research 
and deliberation prior to industrial transfer $[53,54]$. Moreover, potential mycoremediators are suitable for studies that would broaden the understanding of molecular HM resistance mechanisms, and would eventually unlock new decontamination biotechnologies.

This study aimed to explore the diversity and the bioremediation potential of heavy metal resistant fungi. We hypothesized that fungi native to a historically contaminated site must have exceptional HM resistance that can be exploited for the development of bioremediation. Thus, the objectives were to: (i) isolate filamentous fungi from the rhizosphere of plants resident on a former chloralkali facility, and to identify them via internal transcribed spacer region; (ii) establish the isolates' $\mathrm{HMs}$ resistance spectrum $(\mathrm{Hg}, \mathrm{Pb}, \mathrm{Cu}, \mathrm{Zn}$, and $\mathrm{Cd})$ and degree in vitro, in solid media, via tolerance index (TI) and minimum inhibitory concentration (MIC), respectively; and (iii) assess the $\mathrm{Hg}^{2+}$ remediation potential of $\mathrm{HM}$ highly resistant fungal isolates by quantifying their live biomasses removal (\%) and biosorption capacity (mg/g dry weight) in aqueous solution. Additionally, to investigate the functional profile of the community, the HMs resistance patterns were correlated with fungi phylogeny by hierarchical clustering, principal component, and k-means cluster analyses.

\section{Materials and Methods}

\subsection{Site Description and Soil Sampling}

The study site is located at a former chloralkali plant $\left(\mathrm{N}=46.557192^{\circ}, \mathrm{E}=23.781689^{\circ}\right)$ in Turda, Cluj County, Romania, in the vicinity of the Aries river basin $[55,56]$ (Figure 1). The site was chosen for its historical $\mathrm{Hg}$ contamination-about 50 years of activity-since $\mathrm{Hg}$ was used at the cloralkali plant from 1958 as a cathode in the process of $\mathrm{NaCl} / \mathrm{KCl}$ electrolysis to obtain $\mathrm{NaOH} / \mathrm{KOH}$ and chlorine. Later, in the 1980s, plant utilities were extended to produce $\mathrm{Cu}$ and $\mathrm{Zn}$ pesticides, $\mathrm{Ca}(\mathrm{ClO})_{2}$, and other inorganic salts. Once plant activity ceased (late 1990s), the industrial facilities were demolished and abandoned. To date, the area was declared contaminated; yet, 25 years post decommission, no remediation solutions have been adopted $[14,17,57]$. The area is characterized by the Köppen climate classification as Dfb (warm humid continental), with a mean annual temperature of $9^{\circ} \mathrm{C}$ and mean annual precipitation of $571 \mathrm{~mm}$ [58]. Geologically, soils of the area are mostly luvisols derived from clay migration, with the formation of eluvial and illuvial horizons [59]. However, soils sampled as part of this study were classified as Orthents [60], as they were rife with anthropogenic disturbance.

Sampling was performed in June 2018, on the location of the former electrolysis building where $\mathrm{Hg}$ was used as a cathode. The area is about $800 \mathrm{~m}^{2}$ and is mainly covered by demolition debris. Flora and its diversity on the site are scarce. A few species belonging to Brasicaceae, Asteraceae, Fabaceae and Poaceae families were present at the periphery of the demolition residues. Sampling included all the plant species present at the site, without aiming for $\mathrm{Hg}$ hot spots. Twenty rhizosphere soil samples were collected in plastic bags using a stainless-steel hand trowel, from the roots of individual plants scattered around the site's perimeter, at a depth of 5-25 cm [61]. Soil samples were stored at $4{ }^{\circ} \mathrm{C}$ and individually processed for microbial culturing and for elemental analysis within $24 \mathrm{~h}$ upon collection.

\subsection{Reagents, Stock Solutions and Certified Reference Materials}

Single element stock solutions of $0.125 \mathrm{~mol} / \mathrm{L} \mathrm{Hg}^{2+}$ and $1 \mathrm{~mol} / \mathrm{L} \mathrm{Cd}^{2+}, \mathrm{Cu}^{2+}, \mathrm{Pb}^{2+}$, $\mathrm{Zn}^{2+}$ were prepared from $\mathrm{HgCl}_{2}(\geq 99.5 \%), 3 \mathrm{CdSO}_{4} \cdot 8 \mathrm{H}_{2} \mathrm{O}(\geq 99.0 \%), \mathrm{CuSO}_{4}(\geq 99.0 \%)$, $\mathrm{Pb}\left(\mathrm{NO}_{3}\right)_{2}(\geq 99.0 \%)$, and $\mathrm{ZnSO}_{4}(\geq 99.0 \%)$ (Sigma-Aldrich, Munich, Germany). The solutions were sterilized through Millex ${ }^{\circledR}$ Syringe Filter (Merck, Darmstadt, Germany), $0.22 \mu \mathrm{m}$ pore size, and utilized for assessment of fungal HM resistance spectrum in Czapek-Dox agar medium (Formedium, Hunstanton, UK). An aqueous solution of $100 \mathrm{mg} / \mathrm{L} \mathrm{Hg}^{2+}$ was prepared and utilized to assess fungi removal and biosorption potential from supernatants. 


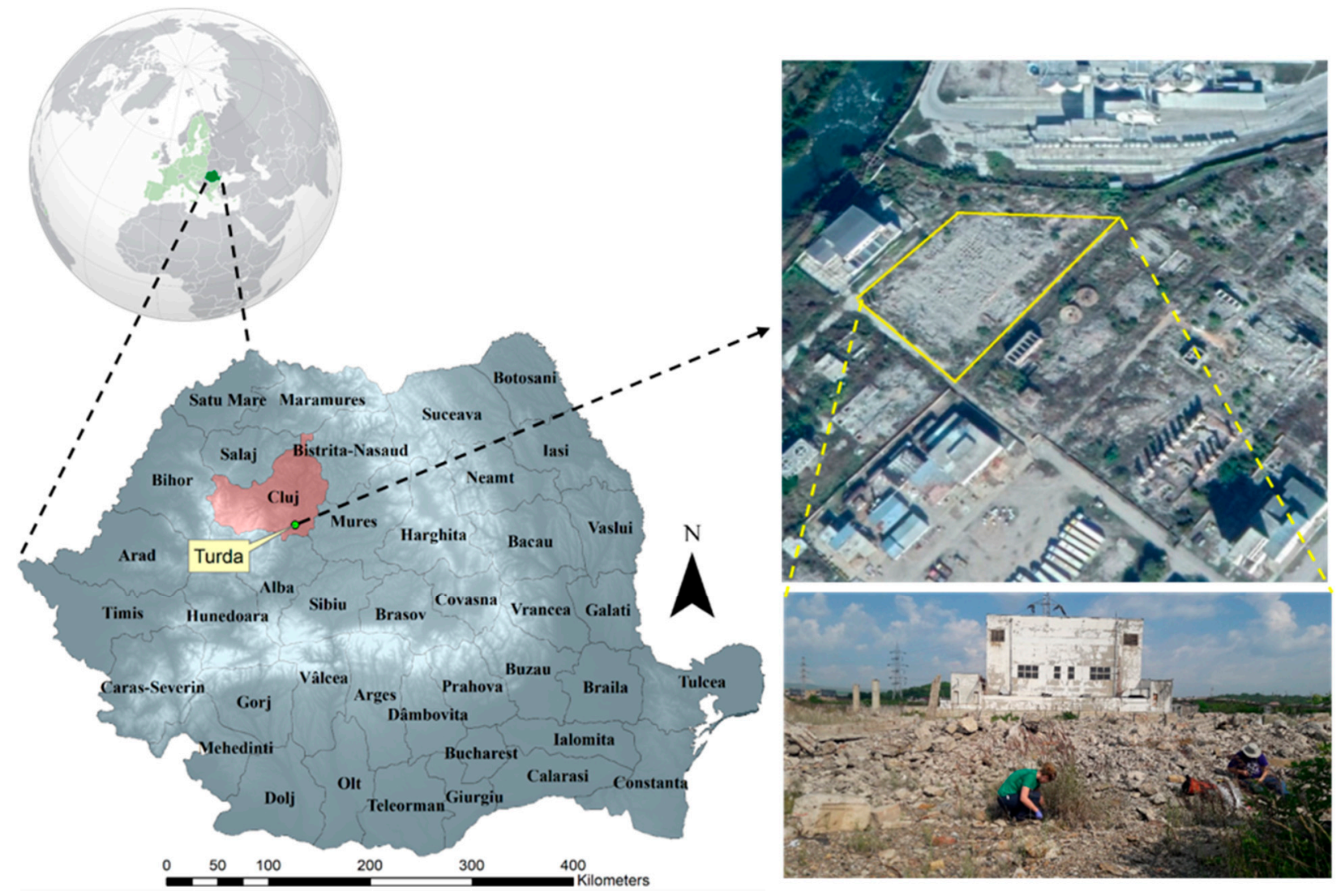

Figure 1. Location of the sampling site in Turda, Romania, in Europe.

Reagents used for supernatant sample preparation and calibration solution dilutions were $\mathrm{HCl} 37 \%$ for $\mathrm{Hg}$ determination $\left(\leq 10^{-4} \% \mathrm{Hg}\right), \mathrm{NaOH}(>98 \%)$, and $\mathrm{NaBH}_{4}$ for analysis, utilized for the preparation of the reaction medium $(3 \% v / v \mathrm{HCl})$, and $0.3 \%(m / v)$ of $\mathrm{NaBH}_{4}$ stabilized in $0.2 \% \mathrm{NaOH}(\mathrm{m} / \mathrm{v})$, needed for $\mathrm{Hg}$ determination by cold vapor high-resolution continuous source quartz furnace atomic absorption spectrometry (CV-HR-CS-QFAAS). Standard solutions in the range of $0-10 \mu \mathrm{g} / \mathrm{mL} \mathrm{Hg}^{2+}(n=9)$ in $3 \%(v / v) \mathrm{HCl}$, prepared from inductively coupled plasma (ICP) standard solution of $1000 \mu \mathrm{g} / \mathrm{mL} \mathrm{Hg}^{2+}$ in $10 \%$ $\mathrm{HNO}_{3}$ (Merck, Darmstadt, Germany) were used for CV-HR-CS-QFAAS calibration [17]. A blank solution $(3 \%(v / v) \mathrm{HCl})$ was used as dilution agent and for the evaluation of the limit of detection ( $3 \sigma$ criterion, $n=11$ ). The content of $\mathrm{Hg}^{2+}$ in supernatant at each sampling time point was determined using a dilution to fit the calibration curve in $3 \% \mathrm{HCl}(v / v)$. Double distilled water was utilized throughout the study for solution preparation and vessel cleaning.

To ensure the accuracy of elemental analysis in fungal supernatants and soil samples, the following certified reference materials were used: ERM-CA713 wastewater certified reference material (Institute for Reference Materials and Measurement, Geel, Belgium) and NIST 2711a-Montana II soil (National Institute of Standards and Technology, Gaithersburg, MD, USA) [62].

\subsection{Elemental Analyses and Quality Control}

The rhizosphere soil samples were analyzed for $\mathrm{Hg}, \mathrm{Pb}, \mathrm{Cu}, \mathrm{Zn}$, and $\mathrm{Cd}$ content by portable X-ray fluorescence (PXRF) with a Vanta series handheld spectrometer (Olympus, Waltham, MA, USA) [63]. The samples were dried at $20^{\circ} \mathrm{C}$ until at constant weight, then ground to fine powder with an agate mortar and a pestle. Samples were massed to infinite thickness on a Prolene thin film placed directly over the instrument aperture mounted in a portable test stand configuration [64]. The instrument was initialized with a 316 stainless steel alloy and operated on line power (115 VAC) at 10-40 keV for $45 \mathrm{~s} /$ beam in Geochem 
Mode. Quality assurance was afforded via scanning NIST 2711a-Montana II soil for the relevant metals of this study: $\mathrm{Hg}, \mathrm{Pb}, \mathrm{Cu}, \mathrm{Zn}$, and $\mathrm{Cd}$. Additionally, a correction factor (CF) for each metal was calculated and applied to the raw detected values a priori [62,65]; data on recovery values and applied CFs are given in Table S1. Further, ecological risk index (RI) was calculated for the metals considered under this study [66]. Pre-industrial reference values used were from the natural background content of upper continental crust $[67,68]$.

Determination of $\mathrm{Hg}$ concentration remaining in supernatants after fungi biosorption was carried out by CV-HR-CS-QFAAS using the ContrAA 300 spectrometer (Analytik Jena, Jena, Germany), equipped with the HS55 batch chemical system generator, in accordance with the manufacturer recommendations. Volumes of $5 \mathrm{~mL}$ calibration solution/sample were pipetted into the reaction cell, where $\mathrm{Hg}$ cold vapors were generated with $3.5 \mathrm{~mL} 0.3 \%$ $(v / v) \mathrm{NaBH}_{4}$ solution stabilized in $0.2 \%(v / v) \mathrm{NaOH}$, pumped via the peristaltic pump for $13 \mathrm{~s}$. Mercury vapors were transported from the reaction cell into the $150 \pm 10^{\circ} \mathrm{C}$ heated quartz tube with a flow rate of $6 \mathrm{~L} / \mathrm{h} \mathrm{Ar}$, where they absorbed the Xe lamp emitted light at $253.652 \mathrm{~nm}$. Signals were processed as peak height from transient signals, registered for a time of $33 \mathrm{~s}$ in a narrow wavelength range $( \pm 0.2 \mathrm{~nm})$, and peak heights were calculated based on 5 pixels. The CV-HR-CS-QFAAS method was validated for mercury determination, with a detection limit of $0.067 \mu \mathrm{g} / \mathrm{L} \mathrm{Hg}^{2+}$ and a recovery in the range of $97 \pm 9 \%$ in ERM-CA713 (certified value $1.84 \pm 0.11 \mu \mathrm{g} / \mathrm{L}$, found value $1.79 \pm 0.16 \mu \mathrm{g} / \mathrm{L}$ for $n=5$ and $95 \%$ confidence level).

\subsection{Fungal Isolation and Heavy Metals Resistance Assays}

Refrigerated soil samples were sieved through a $2 \mathrm{~mm}$ stainless steel sieve and further processed by a routine serial dilution method on Czapek-Dox agar medium, often used for recovery of fungi from HM-contaminated soils [69-72]. The HM resistant fungal isolates were selected upon cultivation on Czapek-Dox agar medium supplemented with single metals $(\mathrm{Hg}, \mathrm{Pb}, \mathrm{Zn}, \mathrm{Cu}$, and $\mathrm{Cd})$, as described in Section 2.2. Metals were added to the autoclaved media and cooled at $\sim 40{ }^{\circ} \mathrm{C}$ from single element stock solutions. The concentration (mg/L) of each metal, $10 \mathrm{Hg}^{2+}, 518 \mathrm{~Pb}^{2+}, 63.5 \mathrm{Cu}^{2+}, 490 \mathrm{Zn}^{2+}$, and $56.2 \mathrm{Cd}^{2+}$, allowed for discrimination between sensitive and resistant isolates, and were chosen considering commonly used concentrations in previously published studies $[43,73,74]$. Medium without metal solution served as control. The plates were centrally inoculated and incubated at $28^{\circ} \mathrm{C}$ for 7 days. Two diameters were recorded and used for the generation of the tolerance index (TI). The TI represents the ratio between the mean of two fungal growth diameters in metal supplemented and control plates [75]. TIs of each fungal isolate were determined for each of the studied metals. The HM resistance was classified based on TIs as follows: 0 -sensitive, $0>\mathrm{TI}>0.29$-very low resistance, $0.30>\mathrm{TI}>0.49$-low resistance, $0.50>\mathrm{TI}>0.69$-moderate resistance, $0.70>\mathrm{TI}>0.89$ - high resistance, and $>0.90$ - very high resistance, adapted from Oladipo et al. [44].

A set of seven fungi was selected for the minimum inhibitory concentration (MIC) assay, based on their superior $\mathrm{Hg}$ and multiple HMs resistance as assessed by TIs. Each isolate was tested for the metals it previously exhibited resistance towards. Potato dextrose agar (PDA) medium was used for comparison with MIC values previously reported $[43,73,74]$. The MIC of each isolate was assessed in triplicate on PDA medium supplemented with increasing concentrations of $\mathrm{Hg}^{2+}, \mathrm{Pb}^{2+}, \mathrm{Cu}^{2+}, \mathrm{Zn}^{2+}$, or $\mathrm{Cd}^{2+}$, adapted for an individual isolate's growth. Plates were centrally inoculated with a $6 \mathrm{~mm}$ diameter fungal disk excised from the edge of 7-day-old pre-grown cultures on PDA. The MIC was recorded upon incubation at $28^{\circ} \mathrm{C}$ for 10 days.

\subsection{Species Diversity and Phylogeny}

Isolates that exhibited resistance above moderate ( $T I \geq 0.5)$ for at least one of the investigated metals were identified based on the internal transcribed spacer (ITS) molecular marker. The gDNA was extracted using the Animal and Fungi DNA preparation kit (Jena Bioscience, Jena, Germany, \#PP-208L), as per manufacturer instructions, and 
used as a template for ITS amplification. The ITS region was amplified using the ITS1F (5'-CTTGGTCATTTAGAGGAAGTAA-3') and ITS4 (5'-TCCTCCGCTTATTGATATGC-3') primers [76,77], and the DreamTaq Green PCR Master Mix $(2 \times)$ (ThermoFisher Scientific, \#K1081). The PCR products were confirmed by electrophoresis in $1 \%$ agarose gel, before purification with GeneJET PCR purification kit (ThermoFisher Scientific, \#K0702). Sequencing was performed with ITS1F primer with an ABI 3730xl system based on capillary electrophoresis sequencing (Macrogen, Amsterdam, The Netherlands). Sequences were examined and manually edited using Chromas (Version 2.6.6, 2018, Technelysium Pty Ltd., South Brisbane, Queensland, Australia). The curated sequences were used as queries in the BLASTn, at NCBI public databases. The species corresponding to the entry with the highest total score was attributed to the inquired sequence. The GenBank accession numbers of the fungal isolates are given in Table S2. Additionally, the ITS sequences were subjected to multiple ClustalW alignment, followed by a 1000 replicate bootstrap analysis to build a neighbor-joining tree in MEGA X software [78], then processed for visualization by iTOL [79]. The ITS sequence from Allomyces arbuscula, AY997028.1, was used as an outgroup because it belongs to the Chytridiomycota phylum, an early diverging clade within Fungi. The phylogeny was used to explore similarities among specific taxa and metal resistance patterns.

\section{6. $\mathrm{Hg}^{2+}$ Biosorption from Aqueous Solution}

$\mathrm{Hg}^{2+}$ removal and biosorption capacities of five distinct fungal species with superior $\mathrm{Hg}$ resistance, were established in aqueous solution supplemented with $100 \mathrm{mg} / \mathrm{L} \mathrm{Hg}^{2+}$, similar to Zafar et al. [32]. Water was selected, as our experiments in Luria Bertani and PDB media, that were used by other authors in similar conditions [39,80], resulted in important media-driven $\mathrm{Hg}$ loss. Seven-day-old PDA fungal cultures were used to prepare the spore suspensions $\left(10^{6}\right.$ spores $\left./ \mathrm{mL}\right)$. Thirty $\mathrm{mL}$ liquid PDB medium was inoculated in triplicate at a final concentration of $10^{4}$ spores $/ \mathrm{mL}$, and incubated for 7 days at $28^{\circ} \mathrm{C}$, $120 \mathrm{r} / \mathrm{min}$. The developed fungal biomass was recovered by vacuum filtration through MF-Millipore ${ }^{\mathrm{TM}} \mathrm{MCE}$ membrane filters (Merck, Darmstadt, Germany), $0.45 \mu \mathrm{m}$ pore size. Washed fungal biomass was added to a $100 \mathrm{mg} / \mathrm{L} \mathrm{Hg}^{2+}$ aqueous solution and incubated for 2 days at $28{ }^{\circ} \mathrm{C}, 120 \mathrm{r} / \mathrm{min}$. The solution without fungal biomass served as control. Fungal biomass removal capacity was monitored by determination of $\mathrm{Hg}^{2+}$ concentration in supernatant, free of cells, collected at $0.5 \mathrm{~h}, 2 \mathrm{~h}, 6 \mathrm{~h}, 12 \mathrm{~h}, 24 \mathrm{~h}$, and $48 \mathrm{~h}$. At each time interval, the fungal cultures were centrifuged at $4300 \mathrm{r} / \mathrm{min}$ for $15 \mathrm{~min}$. Aliquots of $2 \mathrm{~mL}$ supernatant were further centrifuged at $13,000 \mathrm{r} / \mathrm{min}$ for $10 \mathrm{~min}$ to obtain supernatant free of cells. The concentration of $\mathrm{Hg}^{2+}$ in the supernatant free of cells was determined by the CV-HR-CS-QFAAS method. At $48 \mathrm{~h}$, the biomass was recovered by vacuum filtration through MF-Millipore ${ }^{\mathrm{TM}} \mathrm{MCE}$ membrane filters, with $0.45 \mu \mathrm{m}$ pore size, then dried at $33^{\circ} \mathrm{C}$ until at a constant weight. The biosorption capacity $(Q)$ was calculated with Equation (1) [81]:

$$
Q=\left(C_{0}-C\right) V / m,
$$

where $C_{0}(\mathrm{mg} / \mathrm{L})$ and $C(\mathrm{mg} / \mathrm{L})$ are the $\mathrm{Hg}^{2+}$ concentrations at $48 \mathrm{~h}$ in control and in fungal supernatant solutions, respectively; $V(\mathrm{~L})$ is the volume of the solution, and $m(\mathrm{~g})$ is the dry weight (d.w.) of biomass.

\subsection{Statistical Analyses}

One-way analysis of variance (ANOVA) followed by Tukey Pairwise Comparison with $95 \%$ confidence were used to assess differences between means (Minitab ${ }^{\circledR}$ 17.1.0, State College, PA, USA). Matrix-plot was applied to individual TIs in Past 4.03 software [82]. Hierarchical clustering analysis (HCA) of individual TIs, principal component analysis (PCA), and k-means cluster analysis of genera mean TIs, using the 'prcomp' package after scaling, were executed in $\mathrm{R}$ version 3.6.2 [83] to compare HMs resistance patterns with fungi phylogeny. To determine the optimal number of clusters $(\mathrm{k})$, the average silhouette 
approach was used. Library 'cluster' was used in $\mathrm{R}$ to calculate silhouette information, while the 'kmeans' function was used for k-means clustering.

\section{Results}

\subsection{Heavy Metal Concentrations in Rhizosphere Soil}

The basic statistics of variation range and distribution of $\mathrm{Hg}, \mathrm{Pb}, \mathrm{Cu}, \mathrm{Zn}$, and $\mathrm{Cd}$ in the 20 rhizosphere soil samples are presented in Table 1 . The severity of $\mathrm{Hg}$ contamination was confirmed, as values exceeded 3.5 to 200 times the industrial soil threshold intervention value. With respect to $\mathrm{Pb}, 18$ out of 20 rhizosphere soil samples exceeded up to 3.2 times the industrial soil threshold alert value. Ten out of 20 samples exceeded up to 6 times the industrial soil threshold intervention value for $\mathrm{Cu}$, while five exceeded the industrial soil threshold alert value for $\mathrm{Zn}$. Data demonstrate an asymmetric distribution of $\mathrm{Hg}, \mathrm{Cu}$, and $\mathrm{Zn}$ around the mean, i.e., with positive skewness and leptokurtic distribution (kurtosis $>3$ ). With respect to $\mathrm{Pb}$, the distribution is normal and platykurtic. Therefore, the median values were considered to evaluate the ecological risk index (RI) per Hakanson [66]. Although the concentrations of each element varied within the sampling site, very high ecological risk was found for $\mathrm{Hg}(\mathrm{RI}=390,000>600)$, moderate risk for $\mathrm{Pb}(\mathrm{RI}=189>150)$, and low risk for $\mathrm{Zn}, \mathrm{Cu}$, and $\mathrm{Cd}$ for the rhizosphere soil samples.

Table 1. Summary statistics of $\mathrm{Cd}, \mathrm{Cu}, \mathrm{Hg}, \mathrm{Pb}$, and $\mathrm{Zn}(\mathrm{mg} / \mathrm{kg})$ in rhizosphere soil samples by portable X-ray fluorescence (PXRF) spectrometry for polluted soil in Turda, Romania.

\begin{tabular}{|c|c|c|c|c|c|}
\hline & $\mathbf{H g}$ & $\mathrm{Pb}$ & $\mathrm{Cd}$ & $\mathrm{Cu}$ & Zn \\
\hline Minimum & 35 & 54 & $<\mathrm{LOD}^{\mathrm{a}}$ & 40 & 226 \\
\hline Maximum & 4530 & 516 & $<\mathrm{LOD}^{\mathrm{a}}$ & 1699 & 2198 \\
\hline Mean & 1195 & 283 & $-\mathrm{c}$ & 586 & 661 \\
\hline Median & 756 & 266 & $-c$ & 482 & 487 \\
\hline SD & 1107 & 125 & $-c$ & 456 & 477 \\
\hline Skewness & 1.70 & 0.19 & $-c$ & 0.98 & 2.11 \\
\hline Kurtosis & 3.35 & -0.47 & $-c$ & 0.53 & 5.03 \\
\hline Sensitive soil threshold alert ${ }^{b}$ & 1 & 50 & 3 & 100 & 300 \\
\hline $\begin{array}{l}\text { Sensitive soil threshold } \\
\text { intervention } \mathrm{b}\end{array}$ & 2 & 100 & 5 & 200 & 600 \\
\hline Industrial soil threshold alert ${ }^{b}$ & 4 & 150 & 5 & 250 & 700 \\
\hline $\begin{array}{l}\text { Industrial soil threshold } \\
\text { intervention }{ }^{b}\end{array}$ & 10 & 1000 & 10 & 500 & 1500 \\
\hline
\end{tabular}

a LOD-limit of detection, $5 \mathrm{mg} / \mathrm{kg} \mathrm{Cd}{ }^{\text {b }}$ Soil threshold values according to Romanian regulations [84]. ${ }^{\mathrm{c}}$ The parameters could not be calculated for $\mathrm{Cd}$, as the values detected in the rhizosphere soil samples were under the LOD.

\subsection{Identity and Heavy Metal Resistance Phylogenetic Patterns of Isolated Fungi}

The diversity and species abundance of 32 culturable fungal isolates with moderate or higher resistance ( $\mathrm{TI} \geq 0.5$ ) for at least one $\mathrm{HM}$ are illustrated in Figure 2a. Based on their ITS sequences, 25 isolates were identified at the species level, while seven isolates were resolved at the genus level. Ascomycota was the most abundant and diverse phylum recovered as culturable and metal resistant fungi from the investigated site. The isolated Mucoromycota representatives recovered were less diverse, belonging solely to Mortierella alpina (Figure 2b). The fungal community was delineated by Mortierellales, Pleosporales, Capnodiales, Eurotiales, Heliotiales, and Hypocreales orders. Hierarchical clustering analysis (HCA) of individual TIs for $\mathrm{Hg}, \mathrm{Pb}, \mathrm{Cu}, \mathrm{Zn}$, and $\mathrm{Cd}$ was executed to assess whether HMs resistance patterns overlap fungi phylogeny (Figure 2c). Representatives of Pleosporales, here Didymella glomerata, Phoma costaricensis, and Stagonosporopsis sp. HCA sub-cluster (yellow box), displaying a high and very high $\mathrm{Hg}$ and $\mathrm{Pb}$-resistance pattern, reflected their phylogeny. Additionally, Cladosporium sp. (Capnodiales) and Aspergillus sp. (Eurotiales) sub-cluster (pink box), displaying a moderate to very high Hg resistance pattern, coincided with their phylogenetic relationship. However, Penicillium sp. (Euro- 
tiales) were clustered with Mortierella sp. (Mortierellales) (green box), having a moderate Zn resistance pattern and sensitivity for the other contaminants, regardless of their phylogenetic positions. Cadophora malorum (Heliotiales), Sarocladium, Fusarium, and Lecanicillium (Hypocreales) clustering, presenting diverse HMs resistance patterns, resembled their phylogenetic group, although they were fragmented into separate clusters. These observations show that, in heavily Hg-contaminated soil, Ascomycota is the dominant phylum, and that HM resistance patterns within the fungal community overlap phylogenetically in general.

PCA analysis was applied to the mean TIs of each fungal genus for each of the HM assessed to evaluate the community response against metal stress (Figure 3a). The leading two PCs explained $\sim 78 \%$ of the total variance. Examining the loading weights, it was clear that PC1 was dominated by the sum of $\mathrm{Hg}$ and $\mathrm{Cu}, \mathrm{PC} 2$ was dominated by the difference between $(\mathrm{Cu}+\mathrm{Zn})$ and $\mathrm{Pb}$, while $\mathrm{Cd}$ was not strongly associated with the remaining variables. $\mathrm{Cu}$ and $\mathrm{Pb}$ were almost uncorrelated, while $\mathrm{Zn}$ and $\mathrm{Pb}$ were negatively correlated. From the PCA scores, it was clear that Cadophora had high levels of $\mathrm{Cu}$ resistance and moderate levels of $\mathrm{Hg}$ and $\mathrm{Zn}$ resistance. The large PC1 value of Fusarium indicated its high level of $\mathrm{Hg}$ and $\mathrm{Cu}$ resistance. The Sarocladium position corresponded to a moderate $\mathrm{Hg}$ and $\mathrm{Cd}$ resistance. Both Stagonosporopsis and Didymella were at the bottom of the plot, indicating that they likely had high $\mathrm{Pb}$ resistance and a low resistance for $\mathrm{Cu}$ and Zn. Moreover, Mortierella appeared in the leftmost corner of the plot, which implied that it had a low resistance to $\mathrm{Hg}$ and $\mathrm{Cu}$ and moderate $\mathrm{Zn}$ resistance. Both Aspergillus and Cladosporium were in the center, indicating average levels of HM resistance.

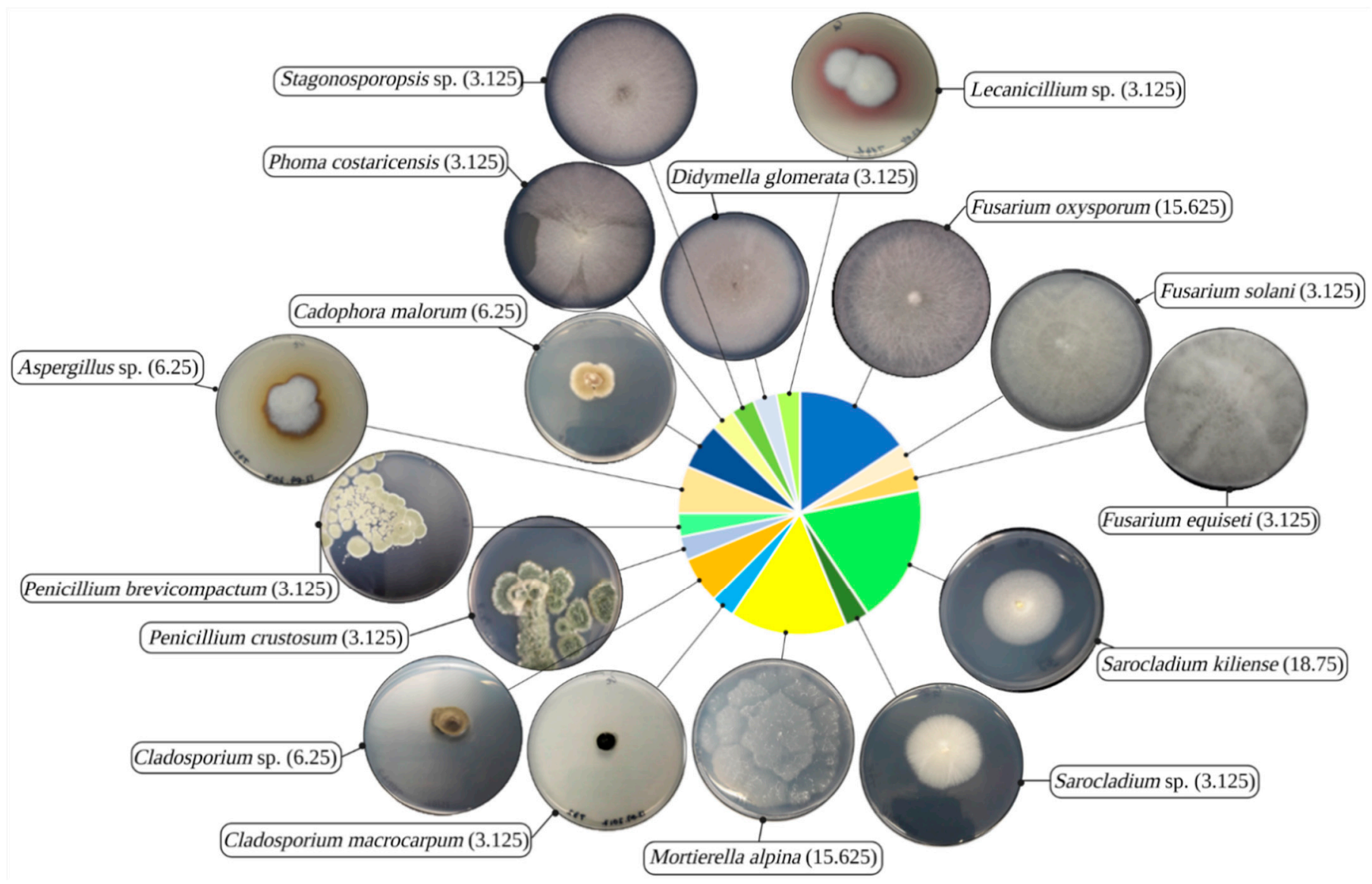

(a)

Figure 2. Cont. 


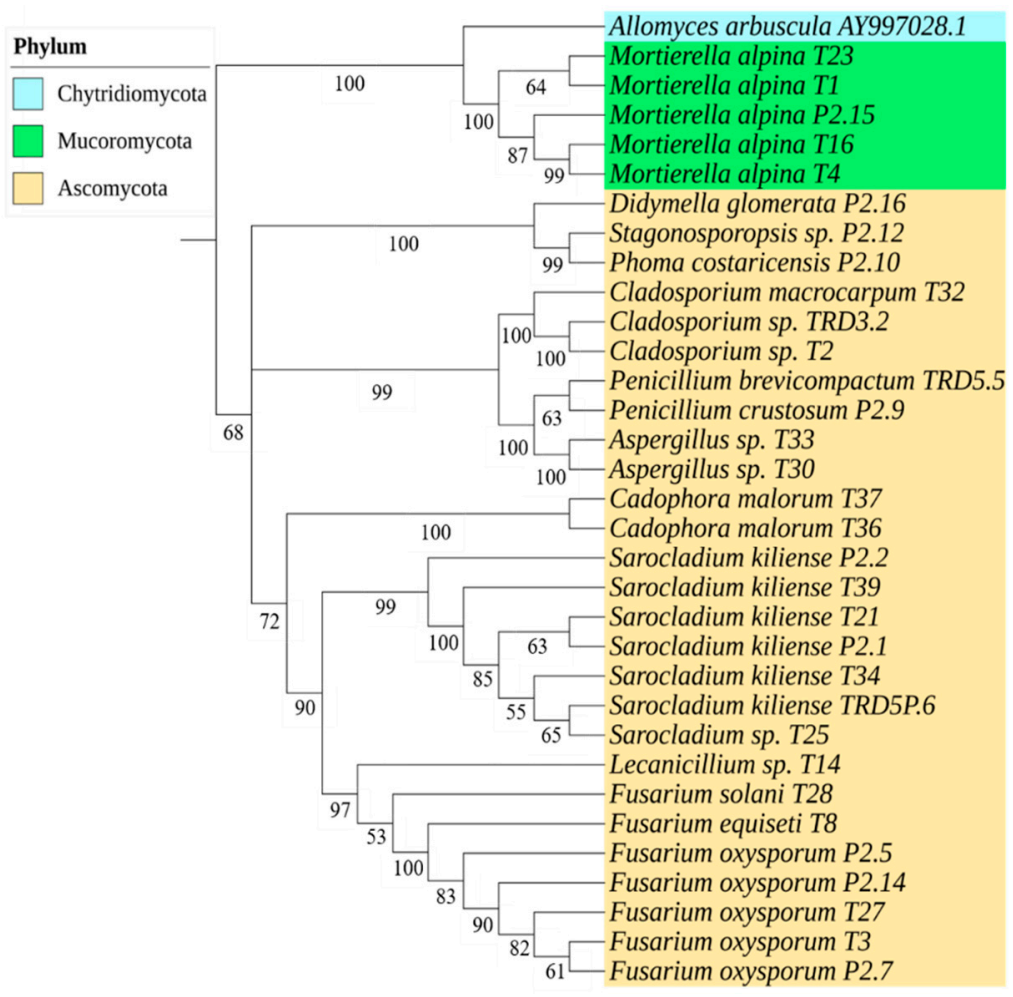

(b)

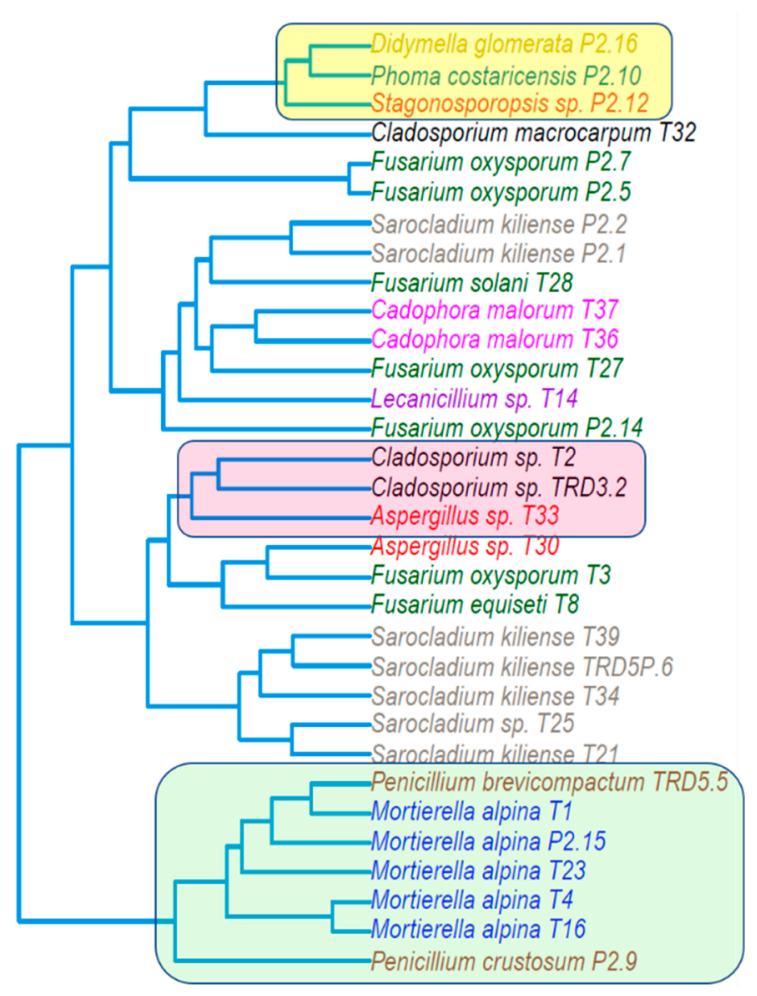

(c)

Figure 2. (a) Composition of the isolated fungal community and the phenotypes of 7-day-old cultures on Czapek-Dox agar, with percentages of species (BioRender, exported on 8 April 2021); (b) species phylogeny (neighbor-joining tree) based on internal transcribed spacer sequences (Allomyces arbuscula AY997028.1 was used as an outgroup); and (c) dendrogram of hierarchical clustering analysis using the individual tolerance indices.

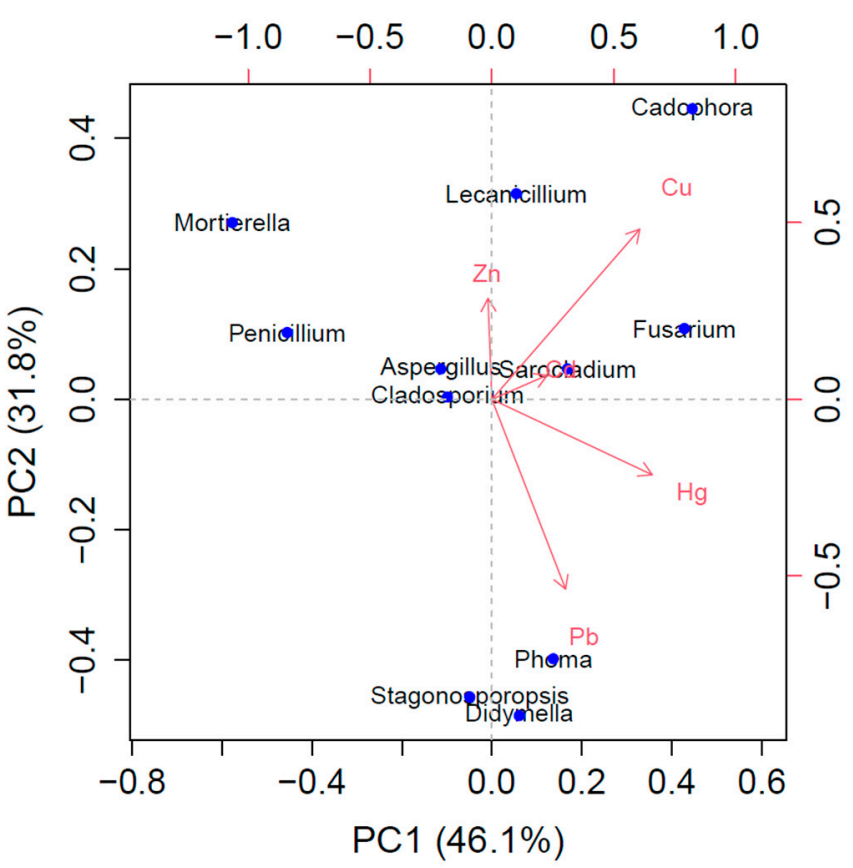

(a)

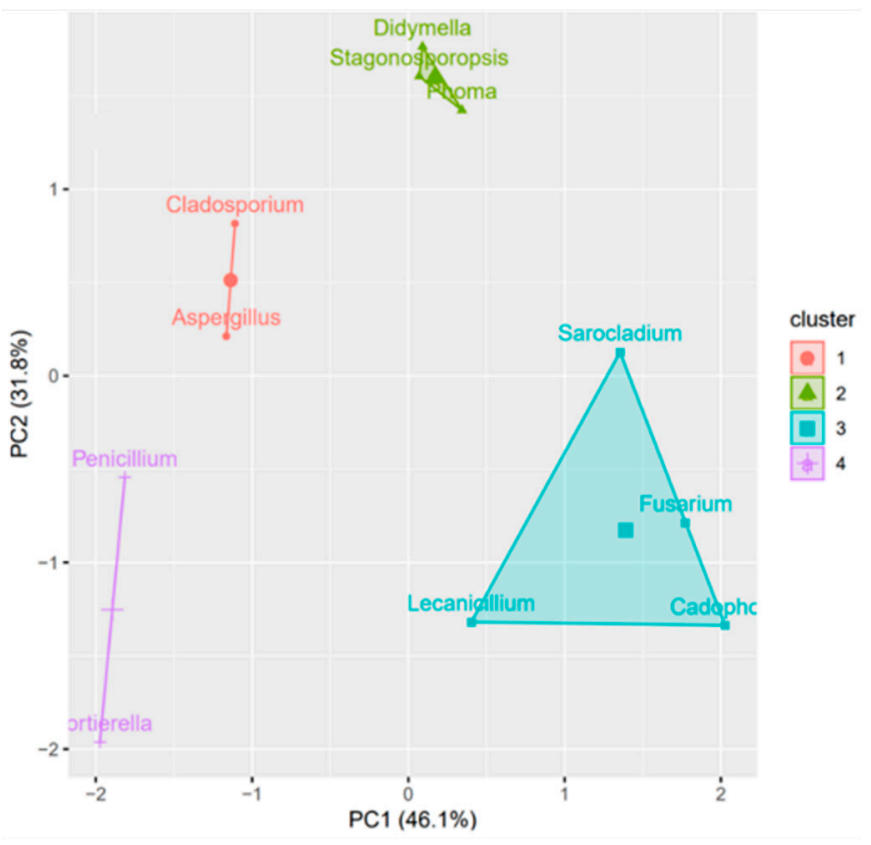

(b)

Figure 3. (a) Principal component (PC) analysis biplot and (b) k-means cluster plot, using the first two principal component scores, applied to the tolerance indices mean of each genus. 
The average silhouettes vs. k plot, when using the genera TIs mean, rendered four optimum clusters that were plotted in the k-means cluster plot (Figure 3b). Cluster 1 defines a moderate or higher Hg-resistance pattern. Cluster 2 specifies a moderate or higher $\mathrm{Hg}$ and very high $\mathrm{Pb}$ resistance pattern. Cluster 3 mostly designates a high and very high $\mathrm{Hg}$ resistance pattern, accompanied occasionally by moderate or higher $\mathrm{Cd}, \mathrm{Cu}$, or $\mathrm{Pb}$ resistance. Cluster 4 represents a sensitive pattern for the contaminants present at the investigated site. The clustering patterns contoured are consistent with those in the PCA plot and HCA diagram. As statistical analyses indicated a degree of relatedness between HMs resistance patterns and phylogenetic relationships, taxonomic group characteristics (i.e., structure and composition of cell walls, type, and quantity of secreted molecules) likely reflect common advantages for representatives of a certain cluster. However, particular characteristics of certain species or isolates contextualize the scattering effect.

\subsection{Fungal Heavy Metal Resistance Spectrum}

The 32 isolated fungi were investigated on Czapek-Dox agar medium for their ability to withstand stress induced by a single element solution of $10 \mathrm{Hg}^{2+}, 518 \mathrm{~Pb}^{2+}, 63.5 \mathrm{Cu}^{2+}$, $490 \mathrm{Zn}^{2+}$, and $56.2 \mathrm{Cd}^{2+}(\mathrm{mg} / \mathrm{L})$. The percentage of isolates that displayed moderate or higher resistance ( $\mathrm{TI} \geq 0.5$ ) for one or more HMs is illustrated in Figure $4 \mathrm{a}$. Single element resistance was detected for $40.63 \%$ of isolates, while $59.37 \%$ withstood stress induced independently by multiple elements. Cadmium and $\mathrm{Cu}$ resistance was always associated with that for $\mathrm{Hg}, \mathrm{Pb}$, or $\mathrm{Zn}$. Single resistance was observed primarily for $\mathrm{Hg}$ (18.75\%), followed by $\mathrm{Zn}(15.63 \%)$ and $\mathrm{Pb}(6.25 \%)$. Since the sampling site is heavily $\mathrm{Hg}$ contaminated, it was not surprising that $71.88 \%$ of the fungal isolates exhibited moderate or higher resistance for this element. Furthermore, $53.13 \%$ of the isolates were $\mathrm{Pb}, \mathrm{Cu}, \mathrm{Zn}$, or Cd-resistant, complementary to $\mathrm{Hg}$.

The proportion of fungal isolates classified according to their resistance degree for each element assessed is shown in Figure $4 \mathrm{~b}$. Most of the isolates, i.e., $81.25 \%$, displayed an Hg-resistance phenotype, predominantly (56.25\%) in the very high and high ranges. In addition to very high and high $\mathrm{Hg}$ resistance, $9.38 \%$ of the isolates were also very highly $\mathrm{Pb}$-resistant. Isolates' resistance for $\mathrm{Zn}, \mathrm{Cu}$, and $\mathrm{Cd}$ was less frequent and/or ranged dominantly from moderate to very low. Only $3.13 \%$ and $15.63 \%$ of isolates displayed high and very high resistance towards $\mathrm{Cd}$ and $\mathrm{Cu}$, respectively. The mean $\mathrm{Hg}$ TIs of fungal isolates was 0.62 , higher than for $\mathrm{Pb}(0.5)$ and significantly higher $(n=32, p<0.001)$ than for $\mathrm{Zn}(0.4), \mathrm{Cu}(0.35)$, and $\mathrm{Cd}(0.27)$. The HMs' occurrence and availability in rhizosphere soil at the investigated site likely represents a selection factor towards a fungal community equipped with effective resistance mechanisms. Since $\mathrm{Cd}$ was not detected by PXRF in the rhizosphere soil samples, whereas $\mathrm{Zn}$ and $\mathrm{Cu}$ are micronutrients constantly uptaken by plant roots, it is probable that these elements had a secondary contribution in shaping the fungal community composition. The $\mathrm{Hg}$ selective pressure on the investigated fungi was demonstrated based on their responses to stress induced by HMs: prevalence of very high and high $\mathrm{Hg}$-resistant phenotypes and specific resistance, primarily to $\mathrm{Hg}$.

The matrix-plot of individual TIs suggestively illustrates isolates' identity in relation to their resistance spectrum and their resistance degree against the assessed contaminants (Figure 4c). Fusarium and Sarocladium genera shared $\mathrm{Hg}$ resistance, although to different degrees, mostly very high and high, respectively. In addition to $\mathrm{Hg}$, Fusarium isolates often had very high $\mathrm{Pb}$ and high to moderate $\mathrm{Zn}$ resistance, while Sarocladium isolates exhibited moderate to very low $\mathrm{Cd}$ resistance. For these isolates, the detoxification mechanisms of $\mathrm{Cd}$ are likely the same as for $\mathrm{Hg}$, since moderate or higher $\mathrm{Cd}$ resistance was always associated with that of $\mathrm{Hg}$. Only one isolate of Cladosporium and of Aspergillus genera displayed very high Hg-resistance. The Cadophora genus commonly had very high $\mathrm{Cu}$ resistance, although the isolates had different degrees of $\mathrm{Hg}$ resistance. Overall, the HMs resistance spectrum is similar among isolates of the same genus, although to different degrees of resistance. Notably, Mortierella alpina isolates were $\mathrm{Cu}$ - and $\mathrm{Hg}$-sensitive, but mostly moderately Zn-resistant, and rarely low Cd-resistant. Isolates with superior HMs 
resistance effectively act as in situ ecological engineers, reducing elements bioavailability they create habitable microconditions for other sensitive microorganisms.

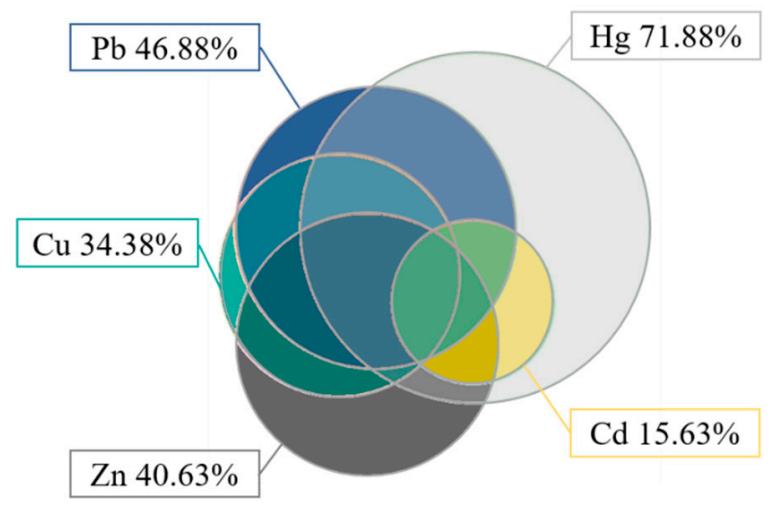

(a)

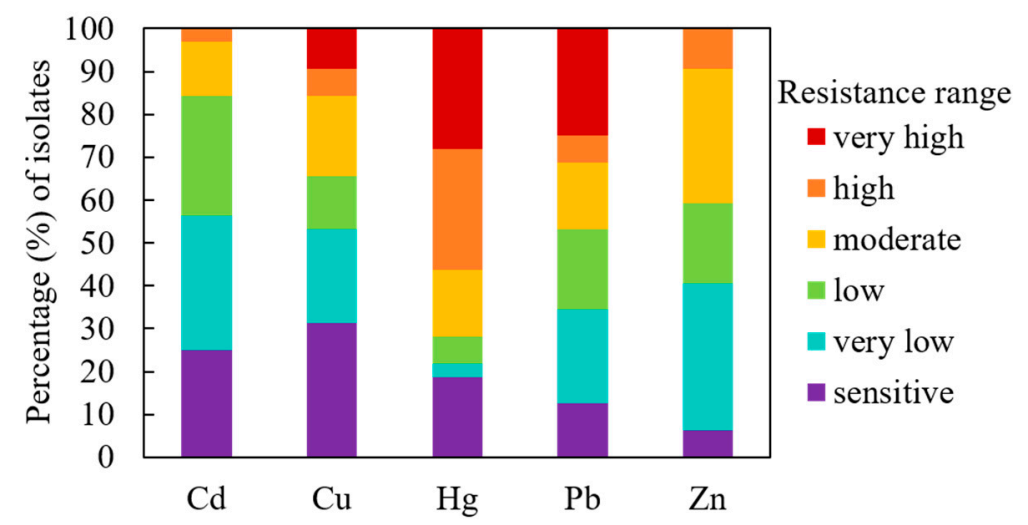

(b)

Mortierella alpina T23 Mortierella alpina $\mathrm{T} 1$

Mortierella alpina P2.15

Mortierella alpina T16

Mortierella alpina $\mathrm{T} 4$

Didymella glomerata P2.16

Stagonosporopsis sp. P2.12

Phoma costaricensis $\mathrm{P} 2.10$

Cladosporium macrocarpum T32

Cladosporium sp. TRD3.2

Cladosporium sp. T2

Penicillium brevicompactum TRD5.5

Penicillium crustosum P2.9

Aspergillus sp. T33

Aspergillus sp. T30

Cadophora malorum T37

Cadophora malorum T36

Sarocladium kiliense P2.2

Sarocladium kiliense T39

Sarocladium kiliense T21

Sarocladium kiliense P2.1

Sarocladium kiliense T34

Sarocladium kiliense TRD5P6

Sarocladium sp. T25

Lecanicillium sp. T14

Fusarium solani $\mathrm{T} 28$

Fusarium equiseti $\mathrm{T} 8$

Fusarium oxysporum P2.5

Fusarium oxysporum $\mathrm{P} 2.14$

Fusarium oxysporum T27

Fusarium oxysporum T3

Fusarium oxysporum P2.7

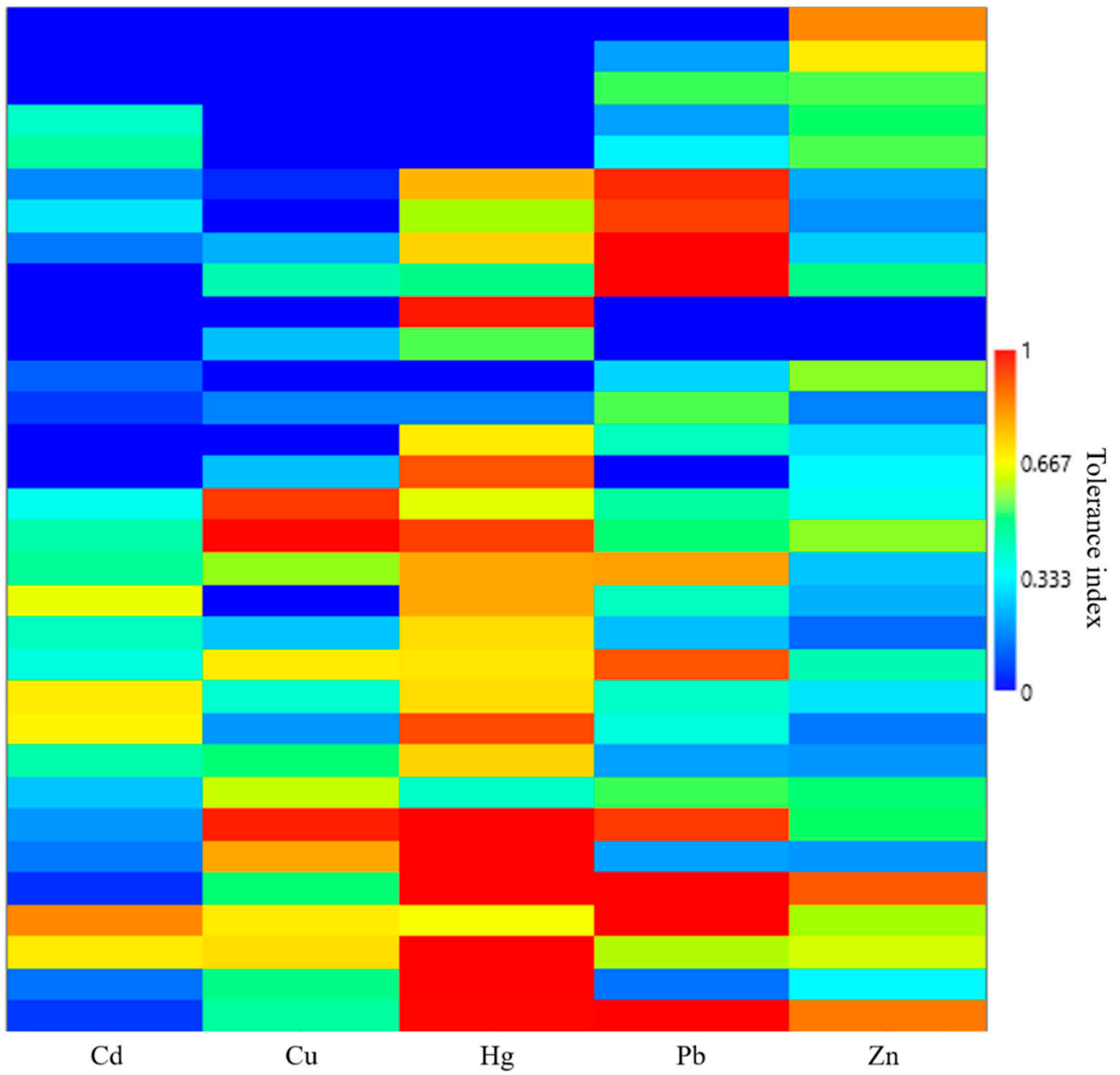

(c)

Figure 4. Fungi community, illustrated as percentages of isolates (a) with single and multiple metals resistance (TI $\geq 5$ ), (b) according to tolerance index ranges, and (c) with matrix-plot of individual TI.

The spectrum of HMs resistance within the fungal community was primarily directed to $\mathrm{Hg}$, followed by $\mathrm{Pb}, \mathrm{Zn}, \mathrm{Cu}$, and $\mathrm{Cd}$. This observation indicated that elements present at the site exerted selective pressure on the fungal population, in accordance with the ecological risk index. Moreover, $\mathrm{Hg}$ resistance of fungi was often coupled with other HMs, suggesting great potential for the development of bioremediation of multiple-contaminated 
substrates. Additionally, it was observed that, although HMs resistance spectra are similar between closely related species, the degree of resistance can be isolate-unique.

The MIC for seven fungal isolates that displayed very high to moderate resistance for one or more metals was established in PDA (Figure 5). The dimension of the outer circle is proportional to fungal growth at 10 days on the control plates, while the inner circles represent growth inhibition induced by the gradually increasing concentrations of tested metal ions $(\mathrm{mg} / \mathrm{L})$, displayed clockwise. The central white dot represents the completely inhibited fungal growth. The MIC value is the mean of at least three independent measurements (Table S3). Fusarium oxysporum P2.5 and P2.7 isolates had MIC values (mg/L) of 140 and 200 for $\mathrm{Hg}, 2353$ and 2092 for $\mathrm{Zn}$, and 1568 and 1568 for $\mathrm{Pb}$, respectively. Phoma costariensis P2.10 and Cladosporium sp. TRD3.2 had Hg MIC values of 160, while Didymella glomerata P2.16 of 200. Sarocladium kiliense P2.2 presented MIC values of $200 \mathrm{for} \mathrm{Hg}, 1036$ for $\mathrm{Pb}$, and 381 for $\mathrm{Cu}$, while S. kiliense TRD5P.6 of 337 and 160 for $\mathrm{Cd}$ and $\mathrm{Hg}$, respectively. Upon this study, Fusarium oxysporum P2.5, Sarocladium kiliense TRD5P.6, Cladosporium sp. TRD3.2, Phoma costaricensis P2.10, and Didymella glomerata P2.16 were selected for the $\mathrm{Hg}^{2+}$ removal and biosorption assay from aqueous solution, as they represent distinct species.

\subsection{Removal and Biosorption Potential of $\mathrm{Hg}^{2+}$ from Aqueous Solution}

The removal and biosorption potential of the live biomasses of five fungal isolates belonging to distinct species was established in $100 \mathrm{mg} / \mathrm{L} \mathrm{Hg}^{2+}$ aqueous solution over $48 \mathrm{~h}$ contact time under shaking conditions $\left(120 \mathrm{r} / \mathrm{min}\right.$ ) (Figure 6). The amount of $\mathrm{Hg}^{2+}$ ranging between $28 \%$ and $52 \%$ was removed by the fungal biomasses in $30 \mathrm{~min}$. Didymella glomerata P2.16 live biomass performed 93\% removal after $2 \mathrm{~h}$ of incubation, and the equilibrium was almost reached within $12 \mathrm{~h}$ by all isolates. At the end of the incubation period, the removal capacity of live biomasses was: $97 \pm 0.4 \%$ (D. glomerata) $>62 \pm 5.1 \%$ (F. oxysporum) $\approx 61 \pm 3.9 \%$ (Cladosporium sp.) $>56 \pm 5.0 \%$ (Phoma costaricensis) $>47 \pm 8.0 \%$ (S. kiliense) (mean $\pm 95 \%$ confidence level, $n=3$ ). The maximum removal capacity of $D$. glomerata biomass was significantly greater $(p<0.0001)$ than the other tested species. This was attributed to the highest biomass developed from spores in the PDB fungal cultures compared to other species. The potential of D. glomerata to form the highest biomass can be further exploited for bioremediation, despite its lower biosorption capacity of $35.8 \pm 0.8 \mathrm{mg} / \mathrm{g}$ d.w. compared to other isolates. Conversely, despite having the lowest removal capacity, S. kiliense exhibited the highest $Q$. This was due to it having the lowest biomass development among the fungal species. The $\mathrm{Hg}^{2+}$ biosorption capacity of the tested fungal biomasses ranged from $33.8 \pm 5.8$ for P. costaricensis to $54.9 \pm 11 \mathrm{mg} / \mathrm{g}$ d.w. for S. kiliense (mean $\pm 95 \%$ confidence level, $n=3$ ). It is likely that the differences in d.w. were due to species characteristic growth rates, although the biomasses were initiated using equivalent spore numbers. 

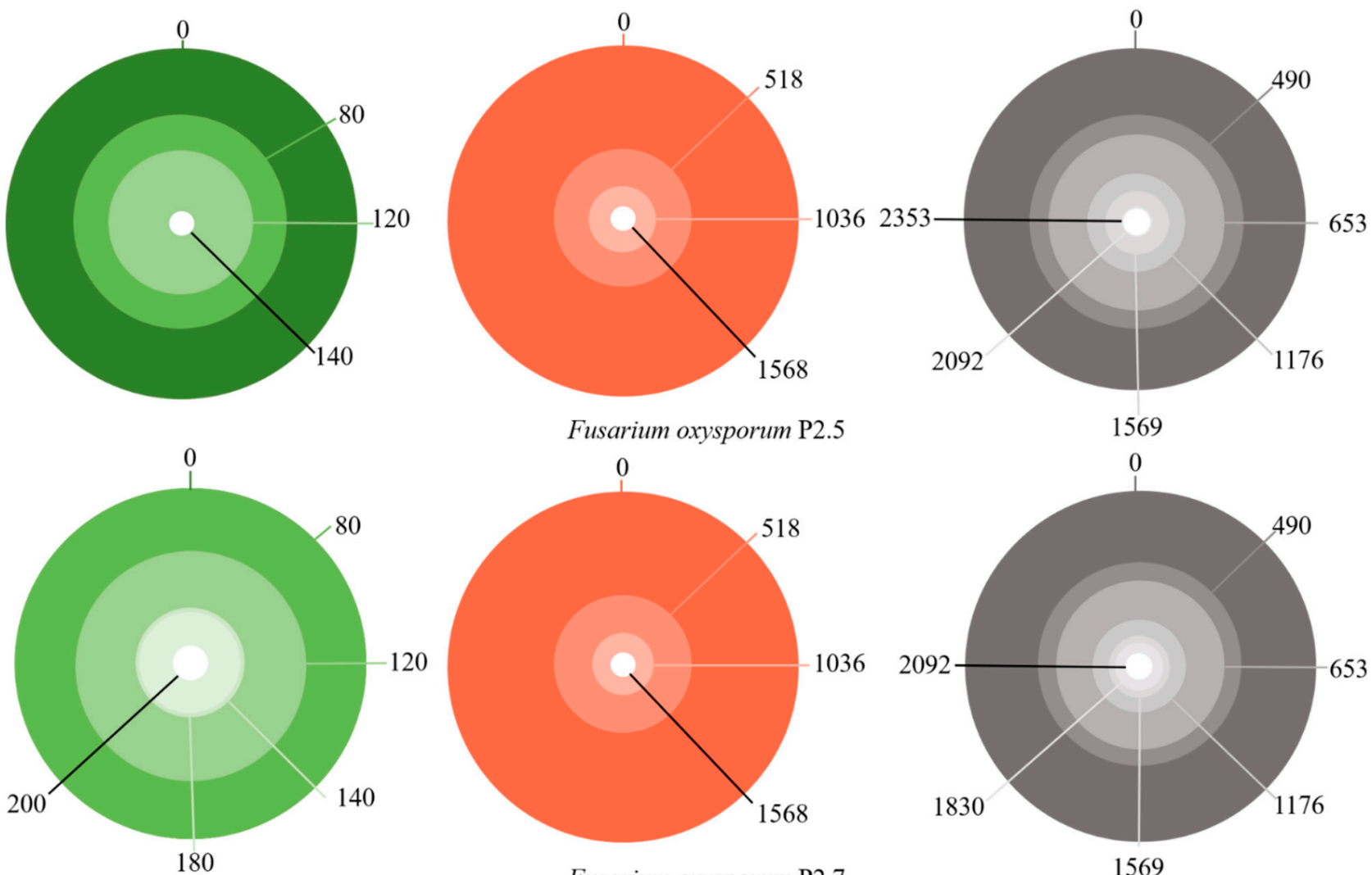

Fusarium oxysporum $\mathrm{P} 2.7$
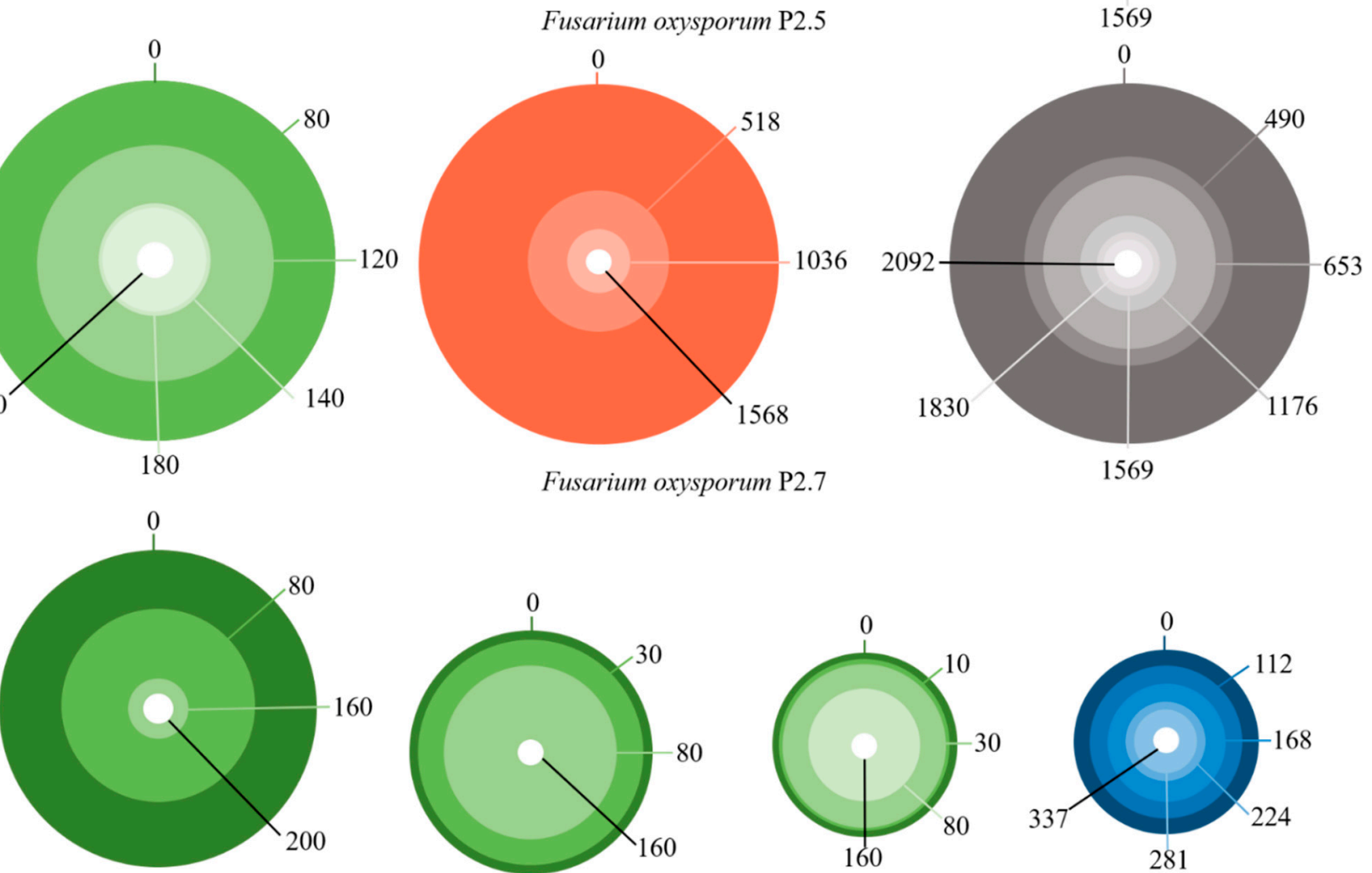

Didymella glomerata P2.16

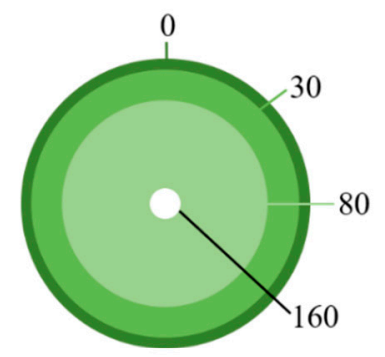

Phoma costaricensis P2.10
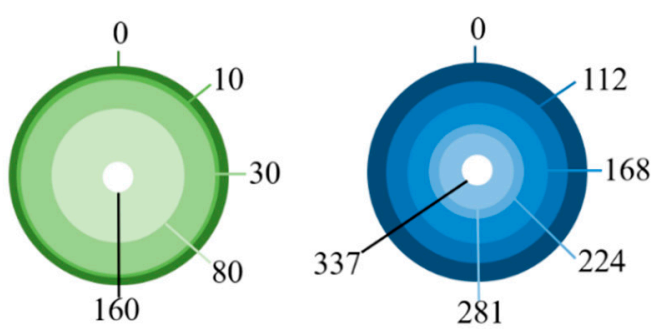

Sarocladium kiliense TRD5P6
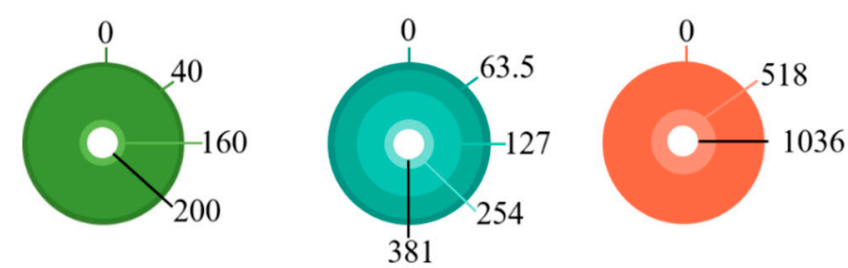

Sarocladium kiliense P2.2

Figure 5. Representation of the minimum inhibitory concentration assay $(\mathrm{mg} / \mathrm{L})$ for investigated fungal species: $\mathrm{Hg}^{2+}$ (green), $\mathrm{Pb}^{2+}$ (red), $\mathrm{Zn}^{2+}$ (gray), $\mathrm{Cd}^{2+}$ (dark blue), $\mathrm{Cu}^{2+}$ (turquoise). 


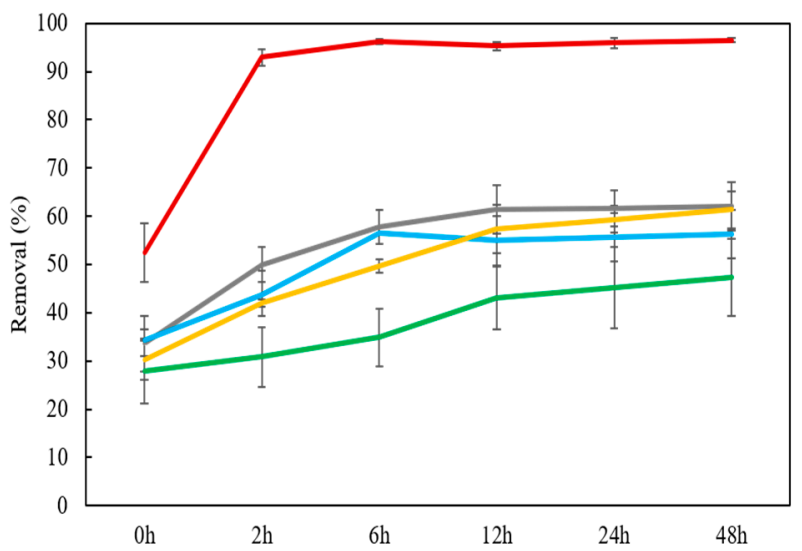

(a)

- Didymella glomerata P2.16
- Fusarium oxysporum P2.5

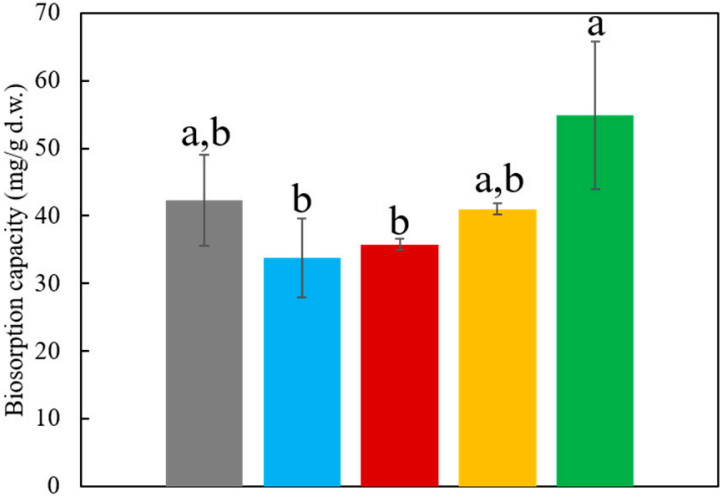

(b)
- Phoma costaricensis P2.10
- Cladosporium sp. TRD3.2
- Sarocladium kiliense TRD5P6

Figure 6. Mercury biosorption potential of five fungal isolates' live biomasses from $100 \mathrm{mg} / \mathrm{L} \mathrm{Hg}^{2+}$ aqueous solution over 48 h, 120 r/min: (a) removal and (b) biosorption capacity; the values represent means, the error bars represent confidence intervals $(n=3,95 \%$ confidence level) and bars with different letters are significantly different (confirmed by Tukey test, $p<0.017)$.

\section{Discussion}

Even though sparingly investigated, fungal communities are consistently found to be more resilient than bacterial ones in HMs contaminated substrates $[37,38,85]$. Metalresistant fungi, autochthonous to contaminated soils, show remarkable degrees of resistance towards HMs. Their bioremediation potential has been recently explored, i.e., HMs removal capacity from single/multi-metal solutions or contaminated soil bioaugmented with fungal consortia, and their ability to assist in phytoremediation of HM-contaminated soil $[24,31,32,43,44,86-88]$. Unique fungal diversity was identified in various HM-contaminated sites $[24,31,43,44,87,88]$. Similar investigations on bacterial populations reflect the same results [56,89-91]. These studies emphasize the need to investigate and make use of microorganism consortia adapted to the particular conditions of each location.

Flora and associated microbiota are appearing at the study site, despite of the severe Hg-contamination. Plants and rhizosphere inhabiting microorganisms must therefore possess mechanisms that allow their survival under extreme conditions. As such, their study for the development of environmental clean-up biotechnologies is timely. The current study investigated the diversity, the metal-resistance profile, and the potential for $\mathrm{Hg}$ bioremediation of filamentous fungi isolated from the rhizosphere of plant species on a former chloralkali facility. Exceedingly high concentrations of $\mathrm{Hg}$, along with elevated concentrations of $\mathrm{Pb}, \mathrm{Cu}$, and $\mathrm{Zn}$, were confirmed via PXRF in the analyzed rhizosphere soil samples. The $\mathrm{Hg}$ selective pressure acted primarily on the studied fungal community, while $\mathrm{Pb}, \mathrm{Zn}, \mathrm{Cu}$, and $\mathrm{Cd}$ had secondary contributions. In general, the HM resistance patterns were shared by closer phylogenetically related isolates. This suggests that, for their survival under HM stress, fungi employ mechanisms characteristic to the taxonomic group they belong to. Beneficial mutations resulted from recombination events, upon repair of double strand breaks induced by HMs, or horizontal gene transfer events [92-94] can grant isolate-unique HM resistance. The diversity and abundance of fungi isolated herein are in accordance with previous data describing Ascomycota as dominant in both natural and HM-contaminated soils [36,38,69,95-97], and Mucoromycota as less frequently recovered from soil with multi-toxic elemental contaminations [69].

The ubiquity of the Ascomycota phylum may be due to several factors: filamentous morphology that enables extended hyphal growth, wind-dispersal, versatility in lifestyles, and a high number of genes related to stress tolerance which provide significant advan- 
tages in colonizing various niches [98]. Isolates of Fusarium and Sarocladium genera, the most frequently recovered from the investigated site, were commonly detected in soil samples associated with mining activities [37,73,99]. The cosmopolitan nature and versatility of these two ascomycetous genera explain their high incidence at the investigated site [100,101]. The preponderance of Fusarium and of other genera identified here (i.e., Penicillium, Lecanicillium, and Phoma) has also been reported in contaminated areas or substrates containing $\mathrm{Cu}, \mathrm{Pb}$, or $\mathrm{Zn}[71,95,102]$. Concerning fungal diversity from a former $\mathrm{Hg}$ mining plant in Rudňany, Slovakia, Cladosporium cladosporioides, Penicillium spp., Aspergillus spp., and Fusarium oxysporum species were recovered [88]. However, the composition of fungal communities is site-specific, influenced by soil composition, properties, and selective pressure of HMs $[37,71,95,99]$. Additionally, the plant community composition, followed by local and seasonal climate variations, are important contributors in shaping fungal communities [103-105]. Herein, new species or genera are reported that were previously unrelated to Hg-contaminated sources: Didymella glomerata, Lecanicillium sp., Fusarium solani, F. equiseti, Sarocladium sp., Penicillium crustosum, P. brevicompactum, Cadophora malorum, Phoma costaricensis, and Stagonosporopsis sp. Most of the isolates belonging to these species exhibited very high and high $\mathrm{Hg}$ resistance.

Mortierella alpina isolates, representatives of Mucoromycota, were recovered infrequently from the rhizosphere soil samples, and exhibited sensitivity for the principal contaminant at the investigated site, $\mathrm{Hg}$, and for $\mathrm{Cu}$. Mortierella genus is known for establishing beneficial associations with plants, providing enhanced growth and stress tolerance against pathogens [106-108]. It is likely that plants are unable to select isolates with increased HM resistance, but may select certain species providing beneficial effects instead. Leguminous plant species on an $\mathrm{Hg}$ contaminated site recruit particular rhizobacteria species, irrespective of the strains' useful traits or HM resistance [109]. Accordingly, plants may not distinguish between HM-resistant or -sensitive strains. Thus, it is possible that Mortierella alpina isolates were engaged by indigenous plant species in symbiotic relationships, due to their responsiveness to root exudates' chemotaxis, irrespective of their inferior metal resistance pattern. However, some of the HM-resistant ascomycetes species isolated herein are known to be involved in plant diseases [101]. We presume that these communities perform in a successive manner, i.e., beneficial fungi colonizing plants' roots grant protection against pathogens throughout the vegetation period, whilst hypothetically phytopathogenic ones thrive as saprotrophs on decaying plant material at the end of plants' life cycle [110] while decreasing HMs' bioavailability until the next season. Conceivably, symbiotic fungi should be considered for phytoremediation approaches assisted by fungal consortia, beside the HM resistant ones. They likely play an essential role, especially in the early stages of plant development.

Concerning the $\mathrm{Cd}, \mathrm{Cu}, \mathrm{Pb}$, and $\mathrm{Zn}$ MIC values reported herein, comparable values were previously documented for Aspergillus, Penicillium, Fusarium, or unidentified isolates in Sabouraud dextrose agar or PDA media $[32,43,74]$. However, Hg MIC values recorded in this study were higher than previously reported for other fungal species in different types of media. Aspergillus flavus withstood up to $100 \mathrm{mg} / \mathrm{L} \mathrm{Hg}$ in PDA [111], while Rhodotorula mucilaginosa, isolated from a sediment sample, was able to grow in the presence of $80 \mathrm{mg} / \mathrm{L}$ $\mathrm{Hg}$ yeast peptone dextrose liquid medium [112]. An Hg-resistant Lecythophora sp. isolate displayed an MIC of $84.5 \mathrm{mg} / \mathrm{L} \mathrm{Hg}$ in LB broth [39]. Penicillium sp. DC-F11, isolated from multiple metals contaminated soil in a mining area, had a $60 \mathrm{mg} / \mathrm{L} \mathrm{Hg} \mathrm{MIC} \mathrm{value} \mathrm{in} \mathrm{LB}$ agar [42]. Therefore, the analysis of MIC for the seven isolates highlighted a significant degree of resistance to $\mathrm{Hg}$ especially, in addition to the other assessed HMs.

Biomasses developed by fungal species isolated from Turda had superior $\mathrm{Hg}^{2+}$ biosorption capacity in aqueous solution, relative to values reported for related studies [80,88,112-117]. However, various fungal and fungal-derived types of biosorbents have previously been investigated for their $\mathrm{Hg}$ removal and $\mathrm{Q}$, under widely variable experimental conditions [40,45,111-118]. Thus, a uniform comparison is unattainable for such heterogeneous conditions. Under similar conditions to those herein, i.e., wet biomass 
in $100 \mathrm{mg} / \mathrm{L} \mathrm{Hg}^{2+}$ aqueous solution, reported Qs were $0.02 \mathrm{mg} / \mathrm{g}$ d.w. for an Hg-resistant Trichoderma virens isolate [80] and $336 \mathrm{mg} / \mathrm{g}$ d.w. for Lentinus edodes, with a $0.89 \mathrm{~m}^{2} / \mathrm{g}$ surface area [45]. Often, powdered fungal biomass was used as an $\mathrm{Hg}^{2+}$ biosorbent because of its higher surface area, relative to live biomass, i.e., $Q$ of 10 and $27 \mathrm{mg} / \mathrm{g} \mathrm{Hg}^{2+}$ in $100 \mathrm{mg} / \mathrm{L} \mathrm{Hg}^{2+}$ solution $[115,117]$. However, superior values for $\mathrm{Hg}$ removal and biosorption capacities obtained herein for fungal isolates from the Turda site, investigated as live biomass, are likely due to the active metabolism of the cells. This facilitates supplementary intracellular uptake, unlike powdered biosorbents. Living fungal cells recovered from contaminated substrates have biosorption capacities in Hg-contaminated medium, in the $0.017-40.2 \mathrm{mg} / \mathrm{g} \mathrm{Hg}^{2+}$ range $[80,88,112,118]$. Finally, the $\mathrm{Hg}^{2+}$ bioremediation potential from highly contaminated aqueous substrate was demonstrated for five species which were isolated and identified in this study. Didymella glomerata isolate was able to develop sufficient biomass to perform $97 \% \mathrm{Hg}^{2+}$ removal from $100 \mathrm{mg} / \mathrm{L}$ aqueous solution. This is important considering the cost of constituents that might be needed for scaling up this type of biosorbent material. Advanced analyses of these biomasses should establish the specificity for $\mathrm{Hg}$ removal, optimal removal conditions, treatment efficacy for biomass recovery, and number of cycles for usage at a satisfactory removal capacity. Additionally, future research should focus on molecular resistance mechanisms (membrane and vacuolar transporters, metal chelators, etc.) of these fungal isolates. The molecular determinants of fungal HM resistance can be used to aid mycoremediation as a reliable technology.

\section{Conclusions}

The HMs resistance of fungi, isolated from the plant rhizosphere grown on a highly $\mathrm{Hg}$-contaminated site of a decommissioned chloralkali facility, was in accordance with the ecological risk index for the elements concerned $(\mathrm{Hg}>\mathrm{Pb}>\mathrm{Zn}>\mathrm{Cu}>\mathrm{Cd})$. Ascomycota was the dominant phylum in terms of diversity, abundance, multiple HMs, and increased $\mathrm{Hg}$ resistance. The detection of Mucoromycota isolates sensitive to $\mathrm{Hg}$ and $\mathrm{Cu}$ and moderately Zn-resistant suggested that they are likely involved in symbiotic relationships with resident plants. Thus, the association of native HM-resistant fungal isolates with plant-symbiotic ones was emphasized in the development of in situ microbe-assisted phytoremediation of contaminated soil. New species or genera that were previously un-related to Hg-contaminated substrates were identified. Fungi taxonomy reflected their responses to HMs stress, although isolate-specific resistance patterns also occurred. Fusarium oxysporum, Sarocladium kiliense, Didymella glomerata, Phoma costaricensis, and Cladosporium sp. isolates showed important MICs for the studied elements, as well as efficient $\mathrm{Hg}^{2+}$ removal (up to $97 \%$ ) and biosorption capacities (up to $54.9 \mathrm{mg} / \mathrm{g}$ ). The characterization and improvement of the novel biosorbent materials should be further explored for industrial water decontamination. Nevertheless, the high degree of fungal resistance for the spectrum of HMs assessed calls for additional research to identify, isolate, and characterize key molecular metal resistance mechanisms. This knowledge would broaden the understanding of HMs detoxification mechanisms in filamentous fungi and contribute to the progress of bioremediation strategies.

Supplementary Materials: The following are available online at https://www.mdpi.com/article/ 10.3390/jof7050386/s1, Table S1: Recovery of metals in NIST certified reference 2711a (Montana II Soil) and correction factors obtained by portable $\mathrm{X}$-ray fluorescence spectrometry; values represent mean $(n=5)$, Table S2: GenBank accession numbers assigned for heavy metal resistant fungal isolates (with Tolerance Index $\geq 0.5$ for at least one of the metals assessed) germane to contaminated soils in Turda, Romania, Table S3: Mean growth diameters of fungal isolates tested for Minimum Inhibitory Concentration.

Author Contributions: Conceptualization, D.P.; methodology, D.P. and C.L.V.; validation, D.P., D.C.W. and T.F.; formal analysis, S.C., B.L. and T.F.; investigation, C.L.V. and E.C.; resources, D.P., D.C.W., M.P. and T.F.; writing—original draft preparation, C.L.V., D.P., E.C., S.C., B.L. and D.C.W.; writing-review and editing, D.P., T.F., M.P., D.C.W. and C.L.V.; visualization, C.L.V. and D.P.; 
supervision, M.P. and D.P.; project administration, D.P.; funding acquisition, D.P. and C.L.V. All authors have read and agreed to the published version of the manuscript.

Funding: This research and APC was funded by the Romanian National Authority for Scientific Research and Innovation, CNCS-UEFISCDI, project number PN-III-P2-2.1-PED-2019-5254, contract no. 390PED/2020 awarded to DP. The APC was also supported by the project: Entrepreneurship for innovation through doctoral and postdoctoral research, POCU/380/6/13/123886, co-financed by the European Social Fund through the Operational Program for Human Capital 2014-2020. In conducting this research, the authors gratefully acknowledge the BL Allen Endowment in Pedology at Texas Tech University (USA).

Institutional Review Board Statement: Not applicable.

Informed Consent Statement: Not applicable.

Data Availability Statement: Not applicable.

Acknowledgments: We would like to thank Zoltán R. Balázs for his valuable assistance with sampling and soil preparation for PXRF, and to Georgiana M. Muntean and Smaranda O. Boghean for their help with MIC analysis.

Conflicts of Interest: The authors declare no conflict of interest.

\section{References}

1. Fairbrother, A.; Wenstel, R.; Sappington, K.; Wood, W. Framework for Metals Risk Assessment. Ecotoxicol. Environ. Saf. 2007, 68, 145-227. [CrossRef] [PubMed]

2. Mishra, S.; Bharagava, R.N.; More, N.; Yadav, A.; Zainith, S.; Mani, S. Heavy Metal Contamination: An Alarming Threat to Environment and Humand Health. In Environmental Biotechnology: For Sustainable Future; Soboti, R.C., Arora, N.K., Kothari, R., Eds.; Springer: Singapore, 2019; pp. 103-125. [CrossRef]

3. Vareda, J.P.; Valente, A.J.M.; Durães, L. Assessment of heavy metal pollution from anthropogenic activities and remediation strategies: A review. J. Environ. Manag. 2019, 246, 101-118. [CrossRef]

4. Tóth, G.; Hermann, T.; Szatmári, G.; Pásztor, L. Maps of heavy metals in the soils of the European Union and proposed priority areas for detailed assessment. Sci. Total Environ. 2016, 565, 1054-1062. [CrossRef]

5. Van Liedekerke, M.; Prokop, G.; Rabl-Berger, S.; Kibblewhite, M.; Louwagie, G. Progress in the Management of Contaminated Sites in Europe; JRC Reference Reports; Publications Office of the European Union: Luxembourg, 2014. [CrossRef]

6. Panagos, P.; Van Liedekerke, M.; Yigini, Y.; Montanarella, L. Contaminated Sites in Europe: Review of the Current Situation Based on Data Collected through a European Network. J. Environ. Public Health 2013, 2013, 158764. [CrossRef] [PubMed]

7. Zhou, Q.; Yang, N.; Li, Y.; Ren, B.; Ding, X.; Bian, H.; Yao, X. Total concentrations and sources of heavy metal pollution in global river and lake water bodies from 1972 to 2017. Glob. Ecol. Conserv. 2020, 22, e00925. [CrossRef]

8. Skyllberg, U. Chemical Speciation of Mercury in Soil and Sediment. In Environmental Chemistry and Toxicology of Mercury; Liu, G., Cai, Y., O'Driscoll, N., Eds.; John Wiley and Sons: Hoboken, NJ, USA, 2011; pp. 219-258.

9. Silver, S.; Hobman, J.L. Mercury Microbiology: Resistance Systems, Environmental Aspects, Methylation, and Human Health. In Molecular Microbiology of Heavy Metals; Nies, D.H., Silver, S., Eds.; Springer: Berlin/Heidelberg, Germany, 2007; pp. 357-370.

10. Morel, F.M.M.; Kraepiel, A.M.L.; Amyot, M. The Chemical Cycle and Bioaccumulation of Mercury. Annu. Rev. Ecol. Syst. 1998, 29, 543-566. [CrossRef]

11. AMAP/UNEP. Technical Background Report for the Global Mercury Assessment 2018; Arctic Monitoring and Assessment Programme: Oslo, Norway; UN Environment Programme, Chemicals and Health Branch: Geneva, Switzerland, 2019.

12. Obrist, D.; Kirk, J.L.; Zhang, L.; Sunderland, E.M.; Jiskra, M.; Selin, N.E. A review of global environmental mercury processes in response to human and natural perturbations: Changes of emissions, climate, and land use. Ambio 2018, 47, 116-140. [CrossRef] [PubMed]

13. Outridge, P.M.; Mason, R.P.; Wang, F.; Guerrero, S.; Heimbürger-Boavida, L.E. Updated Global and Oceanic Mercury Budgets for the United Nations Global Mercury Assessment 2018. Environ. Sci. Technol. 2018, 52, 11466-11477. [CrossRef] [PubMed]

14. Esbrí, J.M.; Cacovean, H.; Higueras, P. Usage Proposal of a common urban decorative tree (Salix alba L.) to monitor the dispersion of gaseous mercury: A case study from Turda (Romania). Chemosphere 2018, 193, 74-81. [CrossRef] [PubMed]

15. Zhu, W.; Li, Z.; Li, P.; Yu, B.; Lin, C.-J.; Sommar, J.; Feng, X. Re-emission of legacy mercury from soil adjacent to closed point sources of Hg emission. Environ. Pollut. 2018, 242, 718-727. [CrossRef]

16. Navrátil, T.; Šimeček, M.; Shanley, J.B.; Rohovec, J.; Hojdová, M.; Houška, J. The history of mercury pollution near the Spolana chlor-alkali plant (Neratovice, Czech Republic) as recorded by Scots pine tree rings and other bioindicators. Sci. Total Environ. 2017, 586, 1182-1192. [CrossRef] [PubMed]

17. Frentiu, T.; Pintican, B.P.; Butaciu, S.; Mihaltan, A.I.; Ponta, M.; Frentiu, M. Determination, speciation and distribution of mercury in soil in the surroundings of a former chlor-alkali plant: Assessment of sequential extraction procedure and analytical technique. Chem. Cent. J. 2013, 7, 178. [CrossRef] 
18. Grangeon, S.; Guédron, S.; Asta, J.; Sarret, G.; Charlet, L. Lichen and soil as indicators of an atmospheric mercury contamination in the vicinity of a chlor-alkali plant (Grenoble, France). Ecol. Indic. 2012, 13, 178-183. [CrossRef]

19. Suchara, I.; Sucharová, J. Mercury distribution around the Spolana chlor-alkali plant (central Bohemia, Czech Republic) after a catastrophic flood, as revealed by bioindicators. Environ. Pollut. 2008, 151, 352-361. [CrossRef] [PubMed]

20. UNEP/MC/COP.3/INF/9. In Proceedings of the 3rd Conference of the Parties to the Minamata Convention on Mercury (COP3), Geneva, Switzerland, 25-29 November 2019.

21. Wang, Z.; Wang, H.; Wang, H.; Li, Q.; Li, Y. Effect of soil washing on heavy metal removal and soil quality: A two-sided coin. Ecotoxicol. Environ. Saf. 2020, 203, 110981. [CrossRef] [PubMed]

22. Liu, L.; Li, W.; Song, W.; Guo, M. Remediation techniques for heavy metal-contaminated soils: Principles and applicability. Sci. Total Environ. 2018, 633, 206-219. [CrossRef] [PubMed]

23. Wuana, R.A.; Okieimen, F.E. Heavy Metals in Contaminated Soils: A Review of Sources, Chemistry, Risks and Best Available Strategies for Remediation. ISRN Ecol. 2011, 2011, 402647. [CrossRef]

24. Hassan, A.; Periathamby, A.; Ahmed, A.; Innocent, O.; Hamid, F.S. Effective bioremediation of heavy metal-contaminated landfill soil through bioaugmentation using consortia of fungi. J. Soil. Sediment. 2020, 20, 66-80. [CrossRef]

25. Purohit, J.; Chattopadhyay, A.; Biswas, M.K.; Singh, N.K. Mycoremediation of Agricultural Soil: Bioprospection for Sustainable Development. In Mycoremediation and Environmental Sustainability; Prasad, R., Ed.; Springer International Publishing: Cham, Switzerland, 2018; Volume 2, pp. 91-120.

26. Kumar, V.V. Mycoremediation: A Step toward Cleaner Environment. In Mycoremediation and Environmental Sustainability; Prasad, R., Ed.; Springer International Publishing: Cham, Switzerland, 2017; Volume 1, pp. 171-187.

27. Dagher, D.J.; Pitre, F.E.; Hijri, M. Ectomycorrhizal Fungal Inoculation of Sphaerosporella brunnea Significantly Increased Stem Biomass of Salix miyabeana and Decreased Lead, Tin, and Zinc, Soil Concentrations during the Phytoremediation of an Industrial Landfill. J. Fungi 2020, 6, 87. [CrossRef] [PubMed]

28. Soldi, E.; Casey, C.; Murphy, B.R.; Hodkinson, T.R. Fungal Endophytes for Grass Based Bioremediation: An Endophytic Consortium Isolated from Agrostis stolonifera Stimulates the Growth of Festuca arundinacea in Lead Contaminated Soil. J. Fungi 2020, 6, 254. [CrossRef] [PubMed]

29. Ma, Y.; Oliveira, R.S.; Freitas, H.; Zhang, C. Biochemical and Molecular Mechanisms of Plant-Microbe-Metal Interactions: Relevance for Phytoremediation. Front. Plant. Sci. 2016, 7. [CrossRef]

30. Singh, H. Mycoremediation: Fungal Bioremediation; John Wiley and Sons, Inc.: Hoboken, NJ, USA, 2006 ; pp. 1-28.

31. Khan, I.; Aftab, M.; Shakir, S.; Ali, M.; Qayyum, S.; Rehman, M.U.; Haleem, K.S.; Touseef, I. Mycoremediation of heavy metal ( $\mathrm{Cd}$ and $\mathrm{Cr}$ )-polluted soil through indigenous metallotolerant fungal isolates. Environ. Monit. Assess. 2019, 191, 585. [CrossRef] [PubMed]

32. Zafar, S.; Aqil, F.; Ahmad, I. Metal tolerance and biosorption potential of filamentous fungi isolated from metal contaminated agricultural soil. Bioresour. Technol. 2007, 98, 2557-2561. [CrossRef] [PubMed]

33. Kumar, V.; Dwivedi, S.K. Mycoremediation of heavy metals: Processes, mechanisms, and affecting factors. Environ. Sci. Pollut. Res. 2021, 28, 10375-10412. [CrossRef]

34. Robinson, J.R.; Isikhuemhen, O.S.; Anike, F.N. Fungal-Metal Interactions: A Review of Toxicity and Homeostasis. J. Fungi 2021, 7, 225. [CrossRef]

35. Danesh, Y.R.; Tajbakhsh, M.; Goltapeh, E.M.; Varma, A. Mycoremediation of Heavy Metals. In Fungi as Bioremediators; Goltapeh, E.M., Danesh, Y.R., Varma, A., Eds.; Springer: Berlin/Heigelber, Germany, 2013; Volume 32, pp. 245-267.

36. Pathak, A.; Jaswal, R.; Xu, X.; White, J.R.; Edwards, B.; Hunt, J.; Brooks, S.; Rathore, R.S.; Agarwal, M.; Chauhan, A. Characterization of Bacterial and Fungal Assemblages from Historically Contaminated Metalliferous Soils Using Metagenomics Coupled With Diffusion Chambers and Microbial Traps. Front. Microbiol. 2020, 11. [CrossRef]

37. Zeng, X.-Y.; Li, S.-W.; Leng, Y.; Kang, X.-H. Structural and functional responses of bacterial and fungal communities to multiple heavy metal exposure in arid loess. Sci. Total Environ. 2020, 723, 138081. [CrossRef] [PubMed]

38. Frossard, A.; Hartmann, M.; Frey, B. Tolerance of the forest soil microbiome to increasing mercury concentrations. Soil Biol. Biochem. 2017, 105, 162-176. [CrossRef]

39. Chang, J.; Duan, Y.; Dong, J.; Shen, S.; Si, G.; He, F.; Yang, Q.; Chen, J. Bioremediation of Hg-contaminated soil by combining a novel Hg-volatilizing Lecythophora sp. fungus, DC-F1, with biochar: Performance and the response of soil fungal community. Sci. Total Environ. 2019, 671, 676-684. [CrossRef] [PubMed]

40. Hoque, E.; Fritscher, J. A new mercury-accumulating Mucor hiemalis strain EH8 from cold sulfidic spring water biofilms. MicrobiologyOpen 2016, 5, 763-781. [CrossRef]

41. Martínez-Juárez, V.M.; Cárdenas-González, J.F.; Torre-Bouscoulet, M.E.; Acosta-Rodríguez, I. Biosorption of Mercury (II) from Aqueous Solutions onto Fungal Biomass. Bioinorg. Chem. Appl. 2012, 156190. [CrossRef]

42. Chang, J.; Shi, Y.; Si, G.; Yang, Q.; Dong, J.; Chen, J. The bioremediation potentials and mercury(II)-resistant mechanisms of a novel fungus Penicillium spp. DC-F11 isolated from contaminated soil. J. Hazard. Mater. 2020, 396, 122638. [CrossRef]

43. Gururajan, K.; Belur, P.D. Screening and selection of indigenous metal tolerant fungal isolates for heavy metal removal. Environ. Technol. Innov. 2018, 9, 91-99. [CrossRef]

44. Oladipo, O.G.; Awotoye, O.O.; Olayinka, A.; Bezuidenhout, C.C.; Maboeta, M.S. Heavy metal tolerance traits of filamentous fungi isolated from gold and gemstone mining sites. Braz. J. Microbiol. 2018, 49, 29-37. [CrossRef] [PubMed] 
45. Bayramoğlu, G.; Arıca, M.Y. Removal of heavy mercury (II), cadmium (II) and zinc (II) metal ions by live and heat inactivated Lentinus edodes pellets. Chem. Eng. J. 2008, 143, 133-140. [CrossRef]

46. Saad, A.M.; Saad, M.M.; Ibrahim, N.A.; El-Hadedy, D.; Ibrahim, E.I.; El-Din, A.Z.K.; Hassan, H.M. Evaluation of Aspergillus tamarii NRC 3 biomass as a biosorbent for removal and recovery of heavy metals from contaminated aqueous solutions. Bull. Natl. Res. Cent. 2019, 43, 10. [CrossRef]

47. Acosta-Rodríguez, I.; Cárdenas-González, J.F.; Pérez, A.S.R.; Oviedo, J.T.; Martínez-Juárez, V.M. Bioremoval of Different Heavy Metals by the Resistant Fungal Strain Aspergillus niger. Bioinorg. Chem. Appl. 2018, 3457196. [CrossRef]

48. Xia, L.; Xu, X.; Zhu, W.; Huang, Q.; Chen, W. A Comparative Study on the Biosorption of Cd ${ }^{2+}$ onto Paecilomyces lilacinus XLA and Mucoromycote sp. XLC. Int. J. Mol. Sci. 2015, 16, 15670-15687. [CrossRef]

49. Albert, Q.; Baraud, F.; Leleyter, L.; Lemoine, M.; Heutte, N.; Rioult, J.-P.; Sage, L.; Garon, D. Use of soil fungi in the biosorption of three trace metals $(\mathrm{Cd}, \mathrm{Cu}, \mathrm{Pb})$ : Promising candidates for treatment technology? Environ. Technol. 2020, 41, 3166-3177. [CrossRef]

50. Yan, G.; Viraraghavan, T. Mechanism of Biosorption of Heavy Metals by Mucor rouxii. Eng. Life. Sci. 2008, 8, 363-371. [CrossRef]

51. Akar, T.; Tunali, S. Biosorption performance of Botrytis cinerea fungal by-products for removal of Cd(II) and Cu(II) ions from aqueous solutions. Miner. Eng. 2005, 18, 1099-1109. [CrossRef]

52. Arıca, M.Y.; Bayramoğlu, G.; Yılmaz, M.; Bektaş, S.; Genç, Ö. Biosorption of $\mathrm{Hg}^{2+}, \mathrm{Cd}^{2+}$, and $\mathrm{Zn}^{2+}$ by Ca-alginate and immobilized wood-rotting fungus Funalia trogii. J. Haz. Mat. 2004, B109, 191-199. [CrossRef]

53. Fomina, M.; Gadd, G.M. Biosorption: Current perspectives on concept, definition and application. Bioresour. Technol. 2014, 160, 3-14. [CrossRef]

54. Dhankhar, R.; Hooda, A. Fungal biosorption-An alternative to meet the challenges of heavy metal pollution in aqueous solutions. Environ. Technol. 2011, 32, 467-491. [CrossRef] [PubMed]

55. Balázs, H.E.; Schmid, C.A.O.; Feher, I.; Podar, D.; Szatmari, P.-M.; Marincaş, O.; Balázs, Z.R.; Schröder, P. HCH phytoremediation potential of native plant species from a contaminated urban site in Turda, Romania. J. Environ. Manag. 2018, 223, 286-296. [CrossRef]

56. Balázs, H.E.; Schmid, C.A.; Cruzeiro, C.; Podar, D.; Szatmari, P.-M.; Buegger, F.; Hufnagel, G.; Radl, V.; Schröder, P. Postreclamation microbial diversity and functions in hexachlorocyclohexane $(\mathrm{HCH})$ contaminated soil in relation to spontaneous $\mathrm{HCH}$ tolerant vegetation. Sci. Total Environ. 2021, 767, 144653. [CrossRef] [PubMed]

57. Cluj County Council. Cluj County Developmental Strategy 2014-2020; Environmental Report, Part III.; Cluj County Council: Cluj-Napoca, Romania, 2012.

58. Kottek, M.; Grieser, J.; Beck, C.; Rudolf, B.; Rubel, F. World map of the Köppen-Geiger climate classification updated. Meteorol. Z. 2006, 15, 259-263. [CrossRef]

59. Stănilă, A.-L.; Dumitru, M. Soils zones in Romania and pedogenetic processes. Agric. Agric. Sci. Procedia 2016, 10, 135-139. [CrossRef]

60. Soil Survey Staff. Soil Survey Field and Laboratory Methods Manual. Soil Survey Investigations; Rep. 51, Version 2; Kellogg Soil Survey Laboratory: Lincoln, NE, USA, 2014.

61. Schoeneberger, P.J.; Wysocki, D.A.; Benham, E.C. Field Book for Describing and Sampling Soils; Government Printing Office: Lincoln, NE, USA, 2012.

62. McGladdery, C.; Weindorf, D.C.; Chakraborty, S.; Li, B.; Paulette, L.; Podar, D.; Pearson, D.; Kusi, N.Y.O.; Duda, B. Elemental assessment of vegetation via portable X-ray fluorescence (PXRF) spectrometry. J. Environ. Manag. 2018, 210, 210-225. [CrossRef]

63. Weindorf, D.C.; Chakraborty, S. Portable X-ray fluorescence spectrometry analysis of soils. Soil Sci. Soc. Am. J. 2020, 84, 1384-1392. [CrossRef]

64. Kagiliery, J.; Chakraborty, S.; Acree, A.; Weindorf, D.C.; Brevik, E.C.; Jelinski, N.A.; Li, B.; Jordan, C. Rapid quantification of lignite sulfur content: Combining optical and X-ray approaches. Int. J. Coal Geol. 2019, 216, 103336. [CrossRef]

65. Koch, J.; Chakraborty, S.; Li, B.; Kucera, J.M.; Van Deventer, P.; Daniell, A.; Faul, C.; Man, T.; Pearson, D.; Duda, B. Proximal sensor analysis of mine tailings in South Africa: An exploratory study. J. Geochem. Explor. 2017, 181, 45-57. [CrossRef]

66. Hakanson, L. An ecological risk index for aquatic pollution control. A sedimentological approach. Water Res. 1980, 14, 975-1001. [CrossRef]

67. Gustin, M.S.; Lindberg, S.; Marsik, F.; Casimir, A.; Ebinghaus, R.; Edwards, G.; Hubble-Fitzgerald, C.; Kemp, R.; Kock, H.; Leonard, T. Nevada STORMS project: Measurement of mercury emissions from naturally enriched surfaces. J. Geophys. Res. Atmos. 1999, 104, 21831-21844. [CrossRef]

68. Taylor, S.R.; McLennan, S.M. The geochemical evolution of the continental crust. Rev. Geophys. 1995, 33, 241-265. [CrossRef]

69. Šimonovičová, A.; Kraková, L.; Pauditšová, E.; Pangallo, D. Occurrence and diversity of cultivable autochthonous microscopic fungi in substrates of old environmental loads from mining activities in Slovakia. Ecotoxicol. Environ. Saf. 2019, 172, 194-202. [CrossRef]

70. Pogrzeba, M.; Ciszek, D.; Galimska-Stypa, R.; Nowak, B.; Sas-Nowosielska, A. Ecological strategy for soil contaminated with mercury. Plant. Soil 2016, 409, 371-387. [CrossRef]

71. Dirginčiutè-Volodkienė, V.; Pečiulytè, D. Increased soil heavy metal concentrations affect the structure of soil fungus community. Agric. Conspec. Sci. 2011, 76, 27-33.

72. Sas-Nowosielska, A.; Galimska-Stypa, R.; Kucharski, R.; Zielonka, U.; Małkowski, E.; Gray, L. Remediation aspect of microbial changes of plant rhizosphere in mercury contaminated soil. Environ. Monit. Assess. 2008, 137, 101-109. [CrossRef] 
73. Mohammadian, E.; Babai Ahari, A.; Arzanlou, M.; Oustan, S.; Khazaei, S.H. Tolerance to heavy metals in filamentous fungi isolated from contaminated mining soils in the Zanjan Province, Iran. Chemosphere 2017, 185, 290-296. [CrossRef]

74. Ezzouhri, L.; Castro, E.; Moya, M.; Espínola, F.; Lairini, K. Heavy metal tolerance of filamentous fungi isolated from polluted sites in Tangier, Morocco. Afr. J. Microbiol. Res. 2009, 3, 35-48. [CrossRef]

75. Akhtar, S.; Mahmood-ul-Hassan, M.; Ahmad, R.; Suthor, V.; Yasin, M. Metal tolerance potential of filamentous fungi isolated from soils irrigated with untreated municipal effluent. Soil Environ. 2013, 32, 55-62.

76. Gardes, M.; Bruns, T.D. ITS primers with enhanced specificity for basidiomycetes-application to the identification of mycorrhizae and rusts. Mol. Ecol. 1993, 2, 113-118. [CrossRef] [PubMed]

77. White, T.J.; Bruns, T.; Lee, S.; Taylor, J. Amplification and direct sequencing of fungal ribosomal RNA genes for phylogenetics. In PCR Protocols A Guide to Methods and Applications; Innis, M.A., Gelfand, D.H., Sninsky, J.J., White, T.J., Eds.; Academic Press: New York, NY, USA, 1990; Volume 18, pp. 315-322.

78. Kumar, S.; Stecher, G.; Li, M.; Knyaz, C.; Tamura, K. MEGA X: Molecular Evolutionary Genetics Analysis across Computing Platforms. Mol. Biol. Evol. 2018, 35, 1547-1549. [CrossRef] [PubMed]

79. Letunic, I.; Bork, P. Interactive tree of life (iTOL) v3: An online tool for the display and annotation of phylogenetic and other trees. Nucleic Acids Res. 2016, 44, W242-W245. [CrossRef] [PubMed]

80. Hernández-Flores, J.L.; Melo, J.G.B.; Hernández, A.C.; López, M.A.R.; Gutiérrez, C.S.; Gomez, S.R.; Moreno, V.P.; Medina, R.P.C.; Soto, J.H.V.; Hernández, S.P.; et al. Isolation and characterization of mercury resistant Trichoderma strains from soil with high levels of mercury and its effects on Arabidopsis thaliana mercury uptake. Adv. Microbiol. 2018, 8, 600-613. [CrossRef]

81. Volesky, B. Biosorption and me. Water Res. 2007, 41, 4017-4029. [CrossRef]

82. Hammer, Ø.; Harper, D.A.; Ryan, P.D. PAST: Paleontological statistics software package for education and data analysis. Palaeontol. Electron. 2001, 4, 9.

83. R Core Team. R: The R Project for Statistical Computing. 2019. Available online: https://www.r-project.org/ (accessed on 3 March 2021).

84. Ministerial Order. No. 756/1997 Approving the Regulation Concerning the Assessment of Environmental Pollution. Official Gazette Part. I, No. 303bis/06.11.1997. Available online: https://biosol.ro/wp-content/uploads/linkuri/ord-756-din-03-11-1997 -pentru-aprobarea-Reglementarii-privind-evaluarea-poluarii-mediului.pdf (accessed on 3 March 2021). (In Romanian).

85. Njoku, K.L.; Asunmo, M.O.; Ude, E.O.; Adesuyi, A.A.; Oyelami, A.O. The molecular study of microbial and functional diversity of resistant microbes in heavy metal contaminated soil. Environ. Technol. Innov. 2020, 17, 100606. [CrossRef]

86. Dey, P.; Malik, A.; Mishra, A.; Singh, D.K.; von Bergen, M.; Jehmlich, N. Mechanistic insight to mycoremediation potential of a metal resistant fungal strain for removal of hazardous metals from multimetal pesticide matrix. Environ. Pollut. 2020, 262, 114255. [CrossRef]

87. Hindersah, R.; Asda, K.R.; Herdiyantoro, D.; Kamaluddin, N.N. Isolation of mercury-resistant fungi from mercury-contaminated agricultural soil. Agriculture 2018, 8, 33. [CrossRef]

88. Urík, M.; Hlodák, M.; Mikušová, P.; Matúš, P. Potential of microscopic fungi isolated from mercury contaminated soils to accumulate and volatilize mercury (II). Water Air Soil Pollut. 2014, 225, 1-11. [CrossRef]

89. Balazs, H.E.; Schmid, C.A.; Podar, D.; Hufnagel, G.; Radl, V.; Schröder, P. Development of microbial communities in organochlorine pesticide contaminated soil: A post-reclamation perspective. Appl. Soil Ecol. 2020, 150, 103467. [CrossRef]

90. Fashola, M.O.; Ngole-Jeme, V.M.; Babalola, O.O. Heavy Metal Immobilization Potential of Indigenous Bacteria Isolated from Gold Mine Tailings. Int. J. Environ. Res. 2020, 14, 71-86. [CrossRef]

91. Franchi, E.; Cosmina, P.; Pedron, F.; Rosellini, I.; Barbafieri, M.; Petruzzelli, G.; Vocciante, M. Improved arsenic phytoextraction by combined use of mobilizing chemicals and autochthonous soil bacteria. Sci. Total Environ. 2019, 655, 328-336. [CrossRef]

92. Morales, M.E.; Derbes, R.S.; Ade, C.M.; Ortego, J.C.; Stark, J.; Deininger, P.L.; Roy-Engel, A.M. Heavy Metal Exposure Influences Double Strand Break DNA Repair Outcomes. PLoS ONE 2016, 11, e0151367. [CrossRef]

93. Zhang, M.Z.; de C. Pereira e Silva, M.; Maryam, C.D.M.; van Elsas, J.D. The mycosphere constitutes an arena for horizontal gene transfer with strong evolutionary implications for bacterial-fungal interactions. FEMS Microbiol. Ecol. 2014, 89, 516-526. [CrossRef]

94. Schoustra, S.E.; Debets, A.J.M.; Slakhorst, M.; Hoekstra, R.F. Mitotic Recombination Accelerates Adaptation in the Fungus Aspergillus nidulans. PLoS Genet. 2007, 3, e68. [CrossRef]

95. Kerfahi, D.; Ogwu, M.C.; Ariunzaya, D.; Balt, A.; Davaasuren, D.; Enkhmandal, O.; Purevsuren, T.; Batbaatar, A.; Tibbett, M.; Undrakhbold, S. Metal-tolerant fungal communities are delineated by high zinc, lead, and copper concentrations in Metalliferous Gobi Desert Soils. Microb. Ecol. 2020, 79, 420-431. [CrossRef]

96. Lin, Y.; Xiao, W.; Ye, Y.; Wu, C.; Hu, Y.; Shi, H. Adaptation of soil fungi to heavy metal contamination in paddy fields-A case study in eastern China. Environ. Sci. Pollut. Res. 2020, 27, 27819-27830. [CrossRef] [PubMed]

97. Torres-Cruz, T.J.; Hesse, C.; Kuske, C.R.; Porras-Alfaro, A. Presence and distribution of heavy metal tolerant fungi in surface soils of a temperate pine forest. Appl. Soil Ecol. 2018, 131, 66-74. [CrossRef]

98. Egidi, E.; Delgado-Baquerizo, M.; Plett, J.M.; Wang, J.; Eldridge, D.J.; Bardgett, R.D.; Maestre, F.T.; Singh, B.K. A few Ascomycota taxa dominate soil fungal communities worldwide. Nat. Comm. 2019, 10, 2369. [CrossRef] 
99. Stępniewska, H.; Uzarowicz, Ł.; Błońska, E.; Kwasowski, W.; Słodczyk, Z.; Gałka, D.; Hebda, A. Fungal abundance and diversity as influenced by properties of Technosols developed from mine wastes containing iron sulphides: A case study from abandoned iron sulphide and uranium mine in Rudki, south-central Poland. Appl. Soil Ecol. 2020, 145, 103349. [CrossRef]

100. Summerbell, R.C.; Gueidan, C.; Schroers, H.J.; de Hoog, G.S.; Starink, M.; Rosete, Y.A.; Guarro, J.; Scott, J.A. Acremonium phylogenetic overview and revision of Glioimastix, Sarocladium, and Trichothecium. Stud. Mycol. 2011, 68, 139-162. [CrossRef] [PubMed]

101. Webster, J.; Weber, R. Introduction to Fungi, 3rd ed.; Cambridge University Press: Cambridge, UK, 2007 ; pp. 315-389.

102. Li, H.-Y.; Li, D.-W.; He, C.-M.; Zhou, Z.-P.; Mei, T.; Xu, H.-M. Diversity and heavy metal tolerance of endophytic fungi from six dominant plant species in a Pb-Zn mine wasteland in China. Fungal Ecol. 2012, 5, 309-315. [CrossRef]

103. Burns, J.H.; Anacker, B.L.; Strauss, S.Y.; Burke, D.J. Soil microbial community variation correlates most strongly with plant species identity, followed by soil chemistry, spatial location and plant genus. AoB PLANTS 2015, 7, plv030. [CrossRef] [PubMed]

104. Chen, Y.-L.; Xu, T.-L.; Veresoglou, S.D.; Hu, H.-W.; Hao, Z.-P.; Hu, Y.-J.; Liu, L.; Deng, Y.; Rillig, M.C.; Chen, B.-D. Plant diversity represents the prevalent determinant of soil fungal community structure across temperate grasslands in northern China. Soil Biol. Biochem. 2017, 110, 12-21. [CrossRef]

105. Schroeder, J.W.; Martin, J.T.; Angulo, D.F.; Razo, I.A.-D.; Barbosa, J.M.; Perea, R.; Sebastián-González, E.; Dirzo, R. Host plant phylogeny and abundance predict root-associated fungal community composition and diversity of mutualists and pathogens. $J$. Ecol. 2019, 107, 1557-1566. [CrossRef]

106. Ozimek, E.; Hanaka, A. Mortierella Species as the Plant Growth-Promoting Fungi Present in the Agricultural Soils. Agriculture 2021, 11, 7. [CrossRef]

107. Zhang, K.; Bonito, G.; Hsu, C.-M.; Hameed, K.; Vilgalys, R.; Liao, H.-L. Mortierella elongata Increases Plant Biomass among Non-Leguminous Crop Species. Agronomy 2020, 10, 754. [CrossRef]

108. Wani, Z.A.; Kumar, A.; Sultan, P.; Bindu, K.; Riyaz-Ul-Hassan, S.; Ashraf, N. Mortierella alpina CS10E4, an oleaginous fungal endophyte of Crocus sativus L. enhances apocarotenoid biosynthesis and stress tolerance in the host plant. Sci. Rep. 2017, 7, 8598. [CrossRef] [PubMed]

109. Nonnoi, F.; Chinnaswamy, A.; García de la Torre, V.S.; Coba de la Peña, T.; Lucas, M.M.; Pueyo, J.J. Metal tolerance of rhizobial strains isolated from nodules of herbaceous legumes (Medicago spp. and Trifolium spp.) growing in mercury-contaminated soils. Appl. Soil Ecol. 2012, 61, 49-59. [CrossRef]

110. Tennakoon, D.S.; Gentekaki, E.; Jeewon, R.; Kuo, C.H.; Promputtha, I.; Hyde, K.D. Life in leaf litter: Fungal community succession during decomposition. Mycosphere 2021, 12, 406-429. [CrossRef]

111. Kurniati, E.; Arfarita, N.; Imai, T.; Higuchi, T.; Kanno, A.; Yamamoto, K.; Sekine, M. Potential bioremediation of mercurycontaminated substrate using filamentous fungi isolated from forest soil. J. Environ. Sci. 2014, 26, 1223-1231. [CrossRef]

112. Liu, B.; Wang, C.; Liu, D.; He, N.; Deng, X. Hg tolerance and biouptake of an isolated pigmentation yeast Rhodotorula mucilaginosa. PLoS ONE 2017, 12, e0172984. [CrossRef] [PubMed]

113. Das, S.K.; Das, A.R.; Guha, A.K. A study on the adsorption mechanism of mercury on Aspergillus versicolor biomass. Environ. Sci. Technol. 2007, 41, 8281-8287. [CrossRef] [PubMed]

114. Karunasagar, D.; Arunachalam, J.; Rashmi, K.; Naveena Lavanya Latha, J.; Maruthi Mohan, P. Biosorption of inorganic and methyl mercury by a biosorbent from Aspergillus niger. World J. Microbiol. Biotechnol. 2003, 19, 291-295. [CrossRef]

115. Say, R.; Yilmaz, N.; Denizli, A. Removal of Heavy Metal Ions Using the Fungus Penicillium canescens. Adsorp. Sci. Technol. 2003, 21, 643-650. [CrossRef]

116. Yalçinkaya, Y.; Arica, M.Y.; Soysal, L.; Denizli, A.; Genç, Ö.; Bektaș, S. Cadmium and Mercury Uptake by Immobilized Pleurotus sapidus. Turk. J. Chem. 2002, 26, 441-452.

117. Rajamohan, N.; Rajasimman, M. Influence of Process Variables and Kinetic Modelling on Mercury Removal Using Paecilomyces variotii Biomass-Effect of Process Parameters and Kinetics. Asian J. Water Environ. Pollut. 2016, 13, 1-8. [CrossRef]

118. Khan, I.; Ali, M.; Aftab, M.; Shakir, S.; Qayyum, S.; Haleem, K.S.; Tauseef, I. Mycoremediation: A treatment for heavy metalpolluted soil using indigenous metallotolerant fungi. Environ. Monit. Assess. 2019, 191, 622. [CrossRef] [PubMed] 